\title{
DOMINANCE-SUBORDINANCE RELATIONSHIPS IN THE SOUTHEASTERN FIVE-LINED SKINK, EUMECES INEXPECTATUS TAYLOR
}

By

CLEO DUKE WILDER, JR.

\begin{abstract}
A DISSERTATION PRESENTED TO THE GRADUATE COUNCIL OF THE UNIVERSITY OF FLORIDA

IN PARTLAL FULFILLMENT OF THE REQUIREMENTS FOR THE DEGREE OF DOCTOR OF PHILOSOPHY
\end{abstract}

UNIVERSITY OF FLORIDA

June, 1962 


\section{ACKNOWLEDGMENTS}

I am indebted to the members of my graduate cormittee, Dr. Coleman J. Goin (Cha1rman), Dr. Archie Carr, Dr. H. K. Wallace, Dr. J. C. Dickinson, and Dr. Caspar Rappenecker for their valuable criticisms and suggestions, and for their patience during the long course of my graduate program. For their aid and comments concerning statistical methods, I wish to thank Dr. Henry Wallbrunn, Dr. John Howell, and Dr. Vonne Porter (Department of Psychology, Memphis state University).

I am especially grateful to Dr. Franz Sauer, who contributed much through his critical reading of this paper. For his constant encouragement and stimulation throughout this research, Dr. Robert Haubrich receives my deepest appreciation. 
TABLE OF CONYENTS

Page

ACKNOWLEDGMENTS .................... 11

IIST OF TABLES ...................... IV

INTRODUCTION ....................... 1

THE EXPERIMENTAL ANIMAL . . . . . . . . . . . . 10

MATERIALS AND METHODS . . . . . . . . . . . . . 17

DESCRIPTION OF CATEGORIES . . . . . . . . . . . . 21

Aggressive Categories . . . . . . . . . 21

Submiss1ve Categories . . . . . . . . . . . 23

Unclassifled Category .............. 24

STATISTICAL METHODS .. . . . . . . . . . . . . 26

DISCUSSION •. . . . . . . . . . . . . . . . 70

SUMMARY AND CONCLUSIONS ... . . . . . . . . . . 94

LITERATURE CTTED . . . . . . . . . . . . . . 98

BIOGRAPHY .. . . . . . . . . . . . . . . . 106 


\section{LIST OF TABLES}

Table

Paqe

1-A Approaches-Females . . . . . . . . . . 29

1-B Approaches-Males .............. 30

2-A Neck ArchIng-Females .............. 32

2-B Neck Arching--Males ............. 33

3-A Tail Vibration-remales ............ 35

3-B Tail Vibration-Males ........... 36

4-A Touches-Females .............. 38

4-B Touches-Males ................ 39

5-A B1tes-pemales ................ 41

5-B Bites-Males ................ 42

6-A Ta11-Waveg-Females ............. 44

6-B Tail-Waves-Males ............. 45

7-A Movements Away--Females ............ 47

7-B Movements Away--Males ............. 48

8-A Retreatg-remales ............... 50

8-B Retreats--Males .............. 51

9-A : Unclassifled--Females .............. 53

9-B Unclassified--Males .............. 54

10-A Weights of Iizards During Observation

Perlod-Fomales ................ 
Table

10-B Weights of Lizards During Observation

Period--Males ...............

11 Total Contacts for Each Category .......

12-A Rankings for Each Category of

Aggression and for Total Aggression--

Females ................. 58

12-B Rankings for Each Cagegory of

Aggression and for Total Aggression--

Males ...................

13 Rankings for Each Category of

Submission and for Total Submission ..... 60

Rankings for Unclassifled Category ......

15 Rendall coeffictent of Concordance (W)

for Rankings among Aggressive and

submissive Categories ...........

16 Correlations of Rankings In Aggression

and submission between sets ..........

17 Frequency of All Contacts Compared

by sets .................

18 Correlations of Rankings between

Aggression and submission ...........

19 Rank Correlation between Ranks for Total Aggression and Submission and Ranks for Each Unit of Aggression and Submission ....

20 Correlations of Rankings for Unclassified Category with All other Categories and with Total Aggression and submission .....

21 Correlations of Aggressive and submissive Categories with Each other ........ 68

22 Activity Rankings of Isolated Females .....

23 Distribution of Bites According to Body Region 


\section{INTRODUCTYON}

Studies on aggression have been made with subjects from all levels of the animal kingdom. The majority of these have dealt with vertebrate animals and have been concerned with general or specific aspects of soclal relationshlps, Including, in many cases, dominance-subordinance relationships. Such studies with vertebrates, from the ploneer work of schjelderup-Ebobe (1913) until the year 1944, have been amply reviewed by collias (1944), and no attempt will be made to give a general review of that period. Since the review by collias, many more studies have been made on many groups of vertebrates, and also, an increasing number of workers are turning to the invertebrates.

The first evidence of dominance and subordinance in the Chondrichthyes was provided by the work of Allee and Dickinson (1954) with the smooth dogfish, Mustelus cants (Mitch111), In which the most obvious feature was avoldance of head-on contacts by the smaller of two individuals. Investigations in the more widely studied ostelchthyes were freguently of a much more specialized nature. studies have been made of the relationsh1p of social 
organization with such things as territory and "leadershlp" in maze-learning (Greenberg, 1947) in the green sunfish, Lepomis cyanellus, and with position in social hierarchy and amount of growth achieved (Allee, et al.. 1948) in the same species; with the effect of prior residence in the 11ve-bearer, Platypoecilus maculatus (Braddock, 1949); with interapecific competition in two species (Salvelinus fontinalis and Salmo gairdnerf) of trout (Newman, 1956): and with juveniles in the Kamloops trout (stringer and Hoar, 1955). Other studies have dealt with the livebearer, Platypoecilus maculatus (Braddock, 1945), cichlid fishes (Baerends and Baerends-van Roon, 1950), the Slamese fighting fish, Betta splendens (Braddock and Braddock, 1955), and fourteen species of darters (Winn, 1958).

The Amphibla have revealed less information about aggressive activity than any of the five major classes of vertebrates. Nartof (1953) demonstrated a primitive type of territorial behavior in the green frog, Rana clamitans, but saw no active aggression. Test (1954) described a challenge and definite aggression in defense of a territory that seemed to be a part of the daily life of the frog. Phyllobates trinitatis. Pearson (1955) observed possible avoldance reactions around undefended home sites in the spadefoot toad, 
Scaphiopus holbrooki. Haubrich (1961) demonstrated under laboratory conditions a loose type of hierarchical behavior with several levels of aggression in the South African clawed frog, Xenopus laevis. Lutz (1960) described fighting which implied an incipient territoriality centering around nesting holes in the male smith frog. Hyla faber. Grant (1955) observed territoriality in two species of salamanders, Eurycea bislineata and Hemidactylum scutatum in captivity. The The former defended its territory by intimidation and direct assault, while the latter used intimidation only, and those animals not establishing territories starved. Birds, especially domestic fowl, have been widely used in behavior investigations since the work of schjelderupEbbe (1913). Most such recent investigations have dealt with special aspects of the much-minded avian social hierarchy. Using domestlc fowl as subjects, Potter (1949) compared dominance relations among different breeds; Guhl (1945) dealt with differences by age and sex; Douglis (1948) compared resident and part-time members of different flocks; Allee, et al. (1955) studied the effects of testosterone propionate on lower-ranking individuals, Banks and Allee (1957) studied the effects of different flock size on agonistic behavior; and Banks (1956), using the more 
primitive red jungle fowl, Gallus gallus subsp.., studied general hierarchical relationships. Numerous other studies have dealt with other birds, both captive and natural populations. Castoro and Guhl (1958) found differences in aggression and territoriality according to sex in captured pigeons. Sabine (1949) studied inter- and intraspecific dominance relationships in winter flocks of juncos and tree sparrows. Thompson (1960) demonstrated social hierarchles in captive flocks of the house finch and found degree of aggressiveness and size of space inversely correlated in caged birds. Kilham (1961) observed interspecific aggressiveness of myrtle warblers toward woodpeckers and other birds. Andrew (1957), on the basis of work with buntings of the genus Emberiza, questioned the existence of subordination of aggressive behavior to the tendencies to behave sexually or to feed, and to certain other drives. Iaskey (1950) described dominance struggles (without territorial defense) among both male and female cowbirds and considered this to be closely linked with the winning of a mate. Brain (1949) found a dominance order correlated with feeding station in male and female great tits, parus major. Goethe (1953) studied social hierarchies in cage-raised herring gulls and found them to be more similar to chickens than to pigeons. 
Jenkens (1944) descirbed an interspecific pecking order among geese. Boyd (1953) described both individual and family hierarchies in winter flocks of white-fronted geese with the former determined by the latter.

Both fleld and laboratory studies have been concerned with aggressive behavior in mammals. Many of these have dealt with causes of aggression rather than with the nature of social hierarchies, almost as well known in mamnals as in birds. Scott and Fredericson (1951) studied the effects of hormones, hunger, and other factors on the fighting of mice and rats. Fredericson and B1rnbaum (1954) found that hered1tary differences were correlated with dominance in the social relations of mice. Denenberg and Bell (1959) found an inverse relationship between frequency and relative intensity of aggression In mice. Clarke (1956) found male voles to be more aggressive than females and success in fighting to result in dominance. Chitty (1952) concluded that the most important factor limiting the growth of vole populations was intraspecific strife. Balph and stokes (1959) found a straightIne dominance order in deer mice, Peromyscus maniculatus. Saott (1948) found the degree of dominance to be inversely proportional to the amount of fighting on goats. schein and Fohrman (1955) described a straight-line hierarchy in a herd 
of dalry cattle, as did Mclugh (1958) in the American bison In herds of which dominance was depleted as an adaptive advantage, especially in severe winters. Miller, Murphy, and Mirsky (1955) studied the effects of conditioning on an established social hierarchy in a group of rhesus monkeys. Kummer (1957) found 70 elements of social behavior and studied the development of individual social position in the baboon, Papio hamadryas.

Most studies of aggression in Reptilla have been with lizards, especially in the family Iguanidae. Greenberg and Noble (1944) conducted a definitive study under seminatural conditions of the social behavior of the American chameleon, Anolis carolinensis, in whlch aggression was found to be related to mating and maintaining of territories. Gordon (1957) found that a similar situation existed in natural populations of the same species, and further, that a reduction of aggressive behavior in the winter facilitated the formation of hibernating aggregations. Ruibal (1960) analyzed the different patterns of aggression in the territorial and sexual behavior of five spectes of Anolis in Cuba and found distinctive patterns of response among them. Stebbins (1944) described a mild intraspecific competition in the mountain swift, Sceloporus graclosus gractlis. Evans 
(1946) described a soclal hierarchy which included vigorous fighting in the 11zard, Sceloporus gramicus microlepidotus, and another (1951) in the black 11zard, Ctenosaura pectinata, In which aggression was primarlly in the form of bluff and display. Lowe and woodin (1954) described what they considered to be "male type aggressive behavior" in the lizard, Phrymosoma p. platyrhinos, which displayed extraordinary aggression toward any object introduced near it in captivity. Carpenter and Grubits (1960) described several forms of aggressive interaction resulting in the dominance of one male over another in the tree 11zard, Urosaurus ornatus. Miller (1951) observed what he Interpreted as a suggestion of territorial defense in the rucca night lizard, Xantusia vigilis. In the field and experimental studies of the six-lined racerunner, Cnemldophorus sexlineatus, Carpenter (1960) observed that In groups certain animals accounted for most of the aggressive activity, that amallest lizards were most subordinate, that dominant 11zards tended to be more active, that subordinates displayed a peculiar submissive posture, and that aggressive behavior could not be related to territoriality. Fitch (1954) described vicious fighting associated with the breeding season in male five-lined skinks, Eumeces fasclatus, but saw little aggression in females or juveniles. Lowe (1948) 
declared that territorlal behavior is widespread among snakes and that what has frequently been called a "courtship dance" between male and female snakes was in most cases a territorial fight between two males. Lowe (1950) observed flghting, including striking, between two male sidewinders, Crotalus cerastes, and stated that most aggressive behavior in snakes is due to competition involving territory, social discrimination, or sexual dominance. Raney and Josephson (1954) observed fighting between two snapping turles, CheIydra serpentina, after the breeding season, but the sexes were undetermined. Parrish (1958) observed territorial1ty and some indication of a social hierarchy in cpative sea turtles in large tanks.

Many of the earlier studies of aggression in vertebrates, as seen in papers discussed above, were concerned with social hierarchies. This has been especially true of American behaviorists, some of whom (Allee and Dickinson, 1954; Haubrich, 1961) were interested (at least in part) in demonstrating such social hierarchies in certain vertebrate classes for the first time. European ethologists, on the other hands, have tended to make detailed descriptions of behavior patterns and to study the factors that underlie their causation, their genetic basis, their ontogeny, and the survival value and 
evolution of these patterns (Baerends, 1958). This has been seen in the studies of releaser mechanisms (Tinbergen, 1942, 1948, 1953), social facilitation (Darling, 1938, Davies, 1953), displacement activities (Lorenz, 1941; Tinbergen, 1953), and imprinting (Lorenz, 1952). It is a characteristic of the latter group that they deal with behavioral units, most of which are highly stereotyped (Baerends, 1958). The purpose of this study is fourfold: to analyze the phenomenon of aggression in a family of non-social lizards in terms of aggressive units, to see if such aggression shows any of the characteristics of social hierarchies, to relate the units to the whole of aggression, and to analyze the nature of individual differences in aggression in terms of units and the whole. Finally this study has been conducted with the hope that such analyses within different taxonomic groups might lead to a better understanding of the evolutionary relationships of the groups as well as of the evolution of behavior itself. 


\section{THE EXPERIMENTAL ANIMAL}

The southeastern five-lined skink, Eumeces inexpectatus, was described by Taylor (1932). It is considered by Taylor to be a member of the fasciatus group of the genus, and very closely related to Bumeces fasciatus and Eumeces laticeps. Eumeces inexpectatus is found from Virginia to the Florida Keys and west to Louisiana (Conant, 1958). It occupies a wide variety of habitats, from mountain woodlands to dry, open, coastal 1slands. In addition to having a broad geographical overlap with E. fasclatus and E. laticeps, it also appears to overlap these two species ecologically, and the three may sometimes be found together in 1 imited areas. However, E. fasclatus does not occur in most of Florida where the other two are locally abundant. In spite of this local abundance, it is difficult to collect large numbers of either species at a given time.

For purposes of this study it was considered necessary to have a large number of specimens from which to select the experimental animals. Fortunately, there was available on Seahorse Key a large population of Bumeces inexpectatus. This island is located in the Gulf of Mexico, approximately 
five and one-half miles from the mainland and three or four miles from the fishing village of Cedar Key, Levy County, Florida.

Seahorse Key is the most seaward of a group of five major islands (and numerous smaller ones) just off the Gulf coast of Florida and located almost equidistantly between the mouths of the Suwannee and Waccasassa Rivers. The island is approximately one mile long and comprises 104.86 acres above mean low tides (Wharton, 1958). The topography of Seahorse Key is dominated by a long, curving, central ridge with a maximum elevation of 52 feet. The western end of the island flattens out into a broad peninsula which probably does not exceed 10 or 12 feet in elevation. There is no fresh water, even in the form of temporary pools.

The vegetation of Seahorse Key, according to Wharton (1958), resembles a mesophytic mainland habitat. However, it is very dry, and as Whatton points out, lacks such elements as magnolia, American holly, and hackberry. It does not present the classif picture of a self-perpetuating climax hammock which can be found on mainland Florida. Wharton classified the specific plant communities of seahorse Key as: hardwood mesophytic and xerophytic forests, mixed hardwood forest. cherry laurel thicket, palm hammock, and saw palmetto. 
Eumeces inexpectatus was found to be most abundant in the first two of these communities.

Seahorse Key supports what has been described as a "depauperate fauna." Nonetheless, it has unusually large populations of two animals, the southeastern five-lined skink, Eumeces inexpectatus, and cottonmouth, Agkistrodon p. piscivorus. There are no amphibians. Other reptiles include the falrly common American chameleon, Anolis carolinensis. and the somewhat less common ground skink, Iygosoma laterale. worm 11zard, Rhineura floridana, six-lined racerunner, Cnemidophorus sexlineatus, red-talled skink, Eumeces egregius, and crowned snake, Tant 111 a coronata. The only mammals which exert an influence on the Island are the Norway rat, the gray squirrel, and man. One part of the island is seasonally influenced by a large rookery of herons, ibises, and cormorants. It is also frequented by crows and other birds from the mainland.

The population of the southeastern five-lined skink on Seahorse Key seems to represent a much larger concentration of skinks than would be encountered anywhere on the mainland. Because of the physical limits to dispersion and possibly the somewhat limited number of predators, the population is very high. These lizards also have an infinite number of 
hiding places in the very heavy vegetation, the thick leaf mold, the porous, sandy, friable soil, interlaced with roots, and the numerous rotten logs. When the lizards are active, they can be heard scurrying through the leaf mold. On many occasions such activity was observed from one spot for as long as an hour. It was, in part, observations of this type which led to the use of this animal in this study of aggression.

When active on Seahorse Key, skinks are constantly foraging for food. They move among the leaves, sometimes under them for several inches, sometimes on top. At times when moving like this, they seem almost oblivious to outside movement. Thus, on occasion, two animals may be seen almost making contact before either is aware of the other's presence. When this happens one lizard usually darts quickly toward the other and pursues it for several feet. The second lizard retreats just as quickly, sometimes as far as twenty feet. Then each usually resumes its foraging activity. Fitch (1954) describes similar behavior for Eumeces fasciatus. In their daily movements the skinks also frequent logs and fallen trees with some using crevices and hollows as retreats. Most of their activity, however, is on the leaf-covered ground. 
In the field these animals react to either movement or sound of humans, sometimes from many feet, by racing up the nearest tree. If the tree is a cabbage palm, they might go all the way to the top and hide among the dried and broken fronds; if it is an oak, they might disappear on the top side of a limb high up. In almost every case they return to the ground in less than five minutes if the disturbance does not continue.

Because of the agility and speed of the skinks, they were difficult to capture. Trapping by means of hardware cloth funnel traps set against a drift fence of the same material was not successful, so almost all the lizards were caught by hand. This was done in two ways. One method involved the use of numerous nineteen-inch squares of tar roofing scattered through the woods and left in place permanently. A lizard under one of these pieces of roofing could be caught if the collector acted quickly enough. The second method was the more successful. If a lizard was seen on the ground, it was approached carefully and slowly. Usually the skink dashed for the nearest tree, and there the collector attempted to grasp it before it climbed out of reach. Most of the lizards used in this study were captured In this manner. 
Most of the contacts observed in the field prior to this study occurred during the breeding season between members of the same sex. In fact, except during the breeding season in early spring, these lizards are relatively inactive, with most movement occurring between $10 \mathrm{~A} . \mathrm{M}$. and 4 P.M. In habits this animal is essentially solitary, spending most of its time inactive and under cover in hiding. Contacts seen in the field are chance contacts of short duration. In several contacts seen between females, one animal always moved away quickly at the sight of the other. However, among males vigorous chases and fights of short duration occurred before one animal retired from the scene. These exchanges were similar to those described by Fitch (1954) for Eumeces fasciatus. The aggressive and submissive behavior would seem to strengthen its solitary habits. No evidence was ever seen of any territoriality. It should be lacking in this animal for the same reason that it is lacking in Eumeces fasciatus (Fitch, 1954) and Cnemidophorus sexlineatus (Caxpenter, 1960): 1ts habits would preclude the establishment of distinctive territories such as are found in other animals, including lizards (especially Iguanidae).

The behavioral units, or categories (as described in a later section), about which this study is organized, were 
first observed in the laboratory. It was only after these laboratory observations that behavior in the field was seen in terms of units at all. A tall vibration was observed during several encounters between animals. Tail-waving frequently occurred as lizards were being pursued by the collector. Arching of the neck usually preceded the capture of food (most frequently beetles, some of which gave their captors real battles before succumbing) and continuedaas the predator chewed upon 1ts prey. of course, the approach and movement away or retreat occurred during encounters between skinks. On two occasions skinks were observed fighting. They bit, clung, turned, twisted, and rolled, and each time, one retreated from the scene. It appeared that the combatants wereof the same sex. The beginning of neither encounter was witnessed. Whereas such field observations contributed to the total knowledge of the animal, this work is based entirely on laboratory observations. 
MATERIALS AND METHODS

The twenty lizards used in this study were captured in the late spring or early summer of 1959 on seahorse Key, Levy County, Florida. They were kept in captivity for at least one month before they were used in experiments. Each lizard was kept in a separate one-gallon jar in which a handful of leaves had been placed. They were fed from one to five mealworms (larvae of the beetle, Tenebrio sp.) each day and a little water was sprinkled in the jar every two or three days. Once a week each jar was cleaned out and the leaves replenished. During the observation periods each $11 z-$ ard was weighed and measured every week or every two weeks. Throughout their period of captivity 11zards were maintained in the animal room of the Department of Blology, University of Florida. This room was equipped with an air conditioner with thermostat which limited the room temperature to a maximum of approximately $80^{\circ}$ F. $\left(26.5^{\circ}\right.$ c.). Observations on Seahorse Key had Indicated that Eumeces inexpectatus was most active between $75^{\circ}$ and $90^{\circ}$ F. $\quad(23.60$ and $32.1^{\circ}$ C.) . 
The general plan of this study was built around the acquisition of data from a series of observations of paired lizards treated as described below. It had been determined in preliminary work that when two lizards were placed in the space used, they encountered each other often enough to provide data, but still had sufficient room to "maneuver" and avoid aggressive action--at least within a short period. Thus, a series of observations of paired lizards allowed an accumulation of data without the danger of injury or death to experimental animals.

The space used for making observations was a tengallon aquarium, 19-1/2" long by 10-1/8" wide. Fitted in the bottom of the aquarium was a piece of masonite with the rough side turned up. This was done to facilitate the movement of the lizards, for they tended to slip and slide when crawling on the smooth slate bottom. A goose-neck lamp with a 75-watt bulb was positioned so that the bulb was approximately 24 inches above the center of the aquarium bottom. Approximately seven feet above the aquarium bottom a 100-watt bulb in a photoflood reflector was suspended. In addition to producing a constant source of light for observations, these lights also provided a fairly constant temperature in the aquarium which was slightly above room temperature. 
The temperature on the floor of the aquarium during observations ranged from $26^{\circ}$ to $29^{\circ} \mathrm{C}$.

All observations of skink activity were made with the observer seated in front of the aquarium. Because of the responsiveness of the animals to outside movements and sounds, 1t was necessary for the observer to be shlelded from them by means of a curtain. Observations were made through a small eye-level opening in this curtain.

Two groups of lizards were used in this study. The first group was composed of ten females (No. 11-No. 20), and the second group was composed of ten males (No. 31-No. 40). Identification of Individual animals within each group was easily accomplished because of the considerable individual varlation in body size, tail length, proportion of regenerated ta11, color pattern, and behavior. Because of these differences and because they were maintained separately between observations, it was not necessary to mark them in any way. Observations with females were made in the late spring and early summer of 1959; observations with males were made in the summer of 1959. Ten observation periods of fifteen minutes each were made for all possible pair combinations (45) of the ten animals in each group. Thus, each pair was observed for a total of 150 minutes. These ten 
observation periods were conducted in two sets of five each. The first set of five observation periods was completed for all possible pair combinations before the second set of five was started. No lizard was ever paired with any other lizard more than once in a twenty-four hour period. Between the completion of the first set of observations and the beginning of the second, the animals were given a "rest period" of two weeks. The procedure was the same for each sex. The first individual observation period of a set started as the two lizards were released simultaneously in the observation space. (at opposite ends). The remaining four periods of the set followed consecutively without the removal of the animals from the aquarium. With allowances for rest periods for the observer, maintenance of the lizards, and other necessary activities, it was possible to complete from two to five pairings a day in this manner. These pairings were generally made between the hours of 10 A.M. and 4 P.M. which corresponded with the period of greatest activity by the skinks in the laboratory as well as in the field. 


\section{DESCRIPTION OF CATEGORIES}

The recognition of the aggressive and submissive patterns occurred during a long period of preliminary observations of the lizards. Specific behavioral traits began to be recognized as these observations continued.

\section{Aggressive Categories}

It appeared to the observer that there were five more or less distinctive and discreet actions which could be considered as components of aggression. These were approach, neck arching, tail vibration, touch, and bite. The responses of the lizards were helpful in the recognition of these actions. If one lizard reacted to an overt action of another, 1t indicated to the observer that some sort of aggressive behavior had occurred. These lizards may be able to recognize aggression that the observer could not detect. The evidence indicates that the five actions referred to above are five categories that show aggression.

\section{Approach}

A movement of one animal directly toward another was an approach, if it continued until the two animals were 
approximately three or four inches apart. If the approached animal showed any kind of response, it was called an approach regardless of distance. Occasionally, one or both animals would move toward the other while climbing up or attempting to escape from the container. Neither this nor any resulting contact was considered aggression.

Neck Arching

Neck arching was characterized by a sharp tunring of the head downward with the snout to the floor of the container. This resulted in a slight ralsing of the fore part of the body with a sharp flexure in the ralsed portion of the neck. It was always directed toward another lizard. occasionally the animal would maneuver around, always facing the other lizard, while keeping the neck arched.

\section{Tail Vibration}

The vibration of the tail was accomplished as the tail lay extended straight behind the animal. It was shaken very rapidly (sometimes so rapidly that the tail itself was a blur) for a few seconds at a time and repeatedly. This was usually done by the approaching animal on its approach, but was frequently done by the approached animal. It seemed to be one of the first reactions to the discovery of another animal at close range. 
Touch

A touch occurred when one animal made physical contact with any part of another with 1 ts own snout. It usually occurred following an approach and was a definite contact or push.

Bite

A bite occurred whenever one skink snapped at or bit another animal. Not all attempts to bite were successful. The misses were originally recorded separately, but since, as aggression, they all apparently represent the same thing, the total flgures were lumped in the bite category. A record was kept as to whether the bite was made on the head, body, or tail.

\section{Submissive Categorles}

There were three activities which were classified as categories of submission. It was recognized that these activities might be a part of the defnese or escape actions of the animal. However, because of the individual differences In performance when these were compared with aggression, it was felt that the general term "submission" is a useful one In this study. 


\section{Tail Waving}

The waving of the tall was not at all like the tall vibration. Instead, the tail was moved back and forth laterally in a series of slow undulations while the lizard was otherwise motionless. It was usually accompanled by a twitchIng motion near the tip. This was always done by the submissive lizard of a particular contact or pair.

\section{Movement Away}

If, following a contact, one of the skinks crawled away slowly, a movement away was recorded. Such movements away occurred not only after "mild" displays of aggression, but also after vigorous exchanges of bites. It represents a mild but obvious form of avoldance.

\section{Retreat}

The retreat represented a more vigorous form of avoidance than movement away. It was a sudden rush by one animal away from the other, and usually followed physical contact between the two individuals.

\section{Unclassified Category}

Not every contact between pair-mates could be interpreted by the observer as either aggression or submission. 
For example, there were many physical contacts when the activity of the animal was directed toward escape from the container. Such contacts produced no response on the part of either animal to the presence of the other and were recorded as unclassified. 
STATISTICAL METHODS

Tables 1 through 9 show the row-column (frequency of category received compared with frequency delivered) rank correlation. This correlation is the Spearman rank correlation coefficient $\left(r_{\mathrm{s}}\right)$. The computation was made through use of the formula,

$$
r_{s}=1-\frac{6 \sum d^{2}}{N^{3}-N} .
$$

where $r_{\mathrm{s}}=$ rank correlation, $\mathrm{d}=$ difference between rankings, and $N=$ number of animals ranked. The significance level of the rank correlation was determined by consulting a table of critical values of the Spearman rank correlation coefficient (Siegel, 1956, p. 284). The same basic formula was used for the correlations in Tables 16 through 20 and the significance of these correlations was determined in the same manner. The data contributing to Table 11 were used to compare the differences in frequency of contacts occurring in males and females. The test used was the Mann-Whitney U-test which is used to test whether two independent groups have been drawn from the same population. This is considered to be one of the most powerful of the non-parametric tests (siegel, 
1956, p. 116). The significance of the results of this test was also determined from the table of critical values for $v$. The Kendall coefficlent of concordance was used to compare the rankings among aggressive and anong submissive categories. These correlations and the levels of significance are shown in Table 15. The Kendall coefficient of concordance 1s expressed as

$$
w=\frac{\sum\left(R_{j}-\frac{\sum R_{j}}{N}\right)^{2}}{1 / 12 k^{2}\left(N^{3}-N\right)} .
$$

where $r_{j}=$ sum of ranks, $N=$ number of animals ranked, and $k=$ number of sets of rankings (the numerator is usually expressed as $\mathrm{s}$, which, as inserted in the formula above, is the sum of the squares of the observed deviation from the mean of $\left.R_{j}\right)$. The significance of the computed $W$ is determined by the formula,

$$
\chi^{2}=k(N-1) w, \text { with } d f=\mathbb{N - 1} \text { (S1egel, 1956, p. 236). }
$$

Ch1 square was also used in comparing the location of bites received (Table 23) with the expected distribution of random bites. 


\section{TABLES 1-A AND 1-B}

Tables $1-A$ and $1-B$ indicate the number of approaches made by the 11zard numbered in the row across the top toward the 11zard 11sted in the column at the 1eft. rotals at bottom Indicate number of approaches made; at right, number of approaches recelved. 


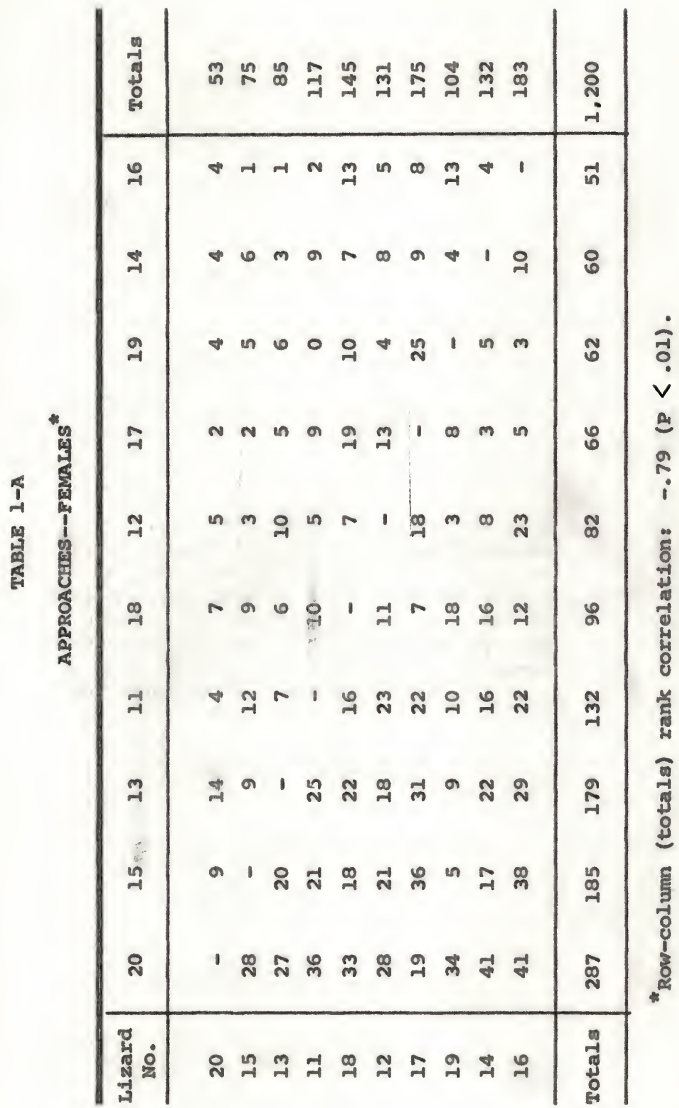




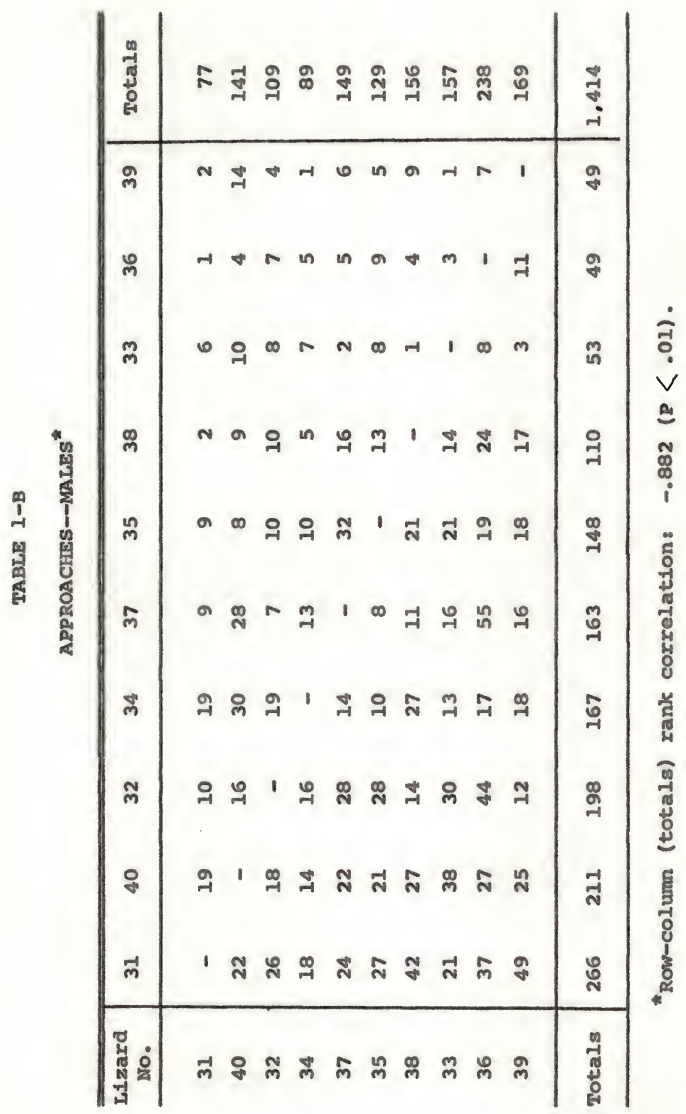


$-31-$

\section{TABLES 2-A AND 2-B}

Tables $2-\mathrm{A}$ and $2-\mathrm{B}$ indicate the number of neck arches made by the lizard numbered in the row across the top toward the lizard listed in the column at the left. Totals at bottom indicate number of arches made; at right, number of arches received. 


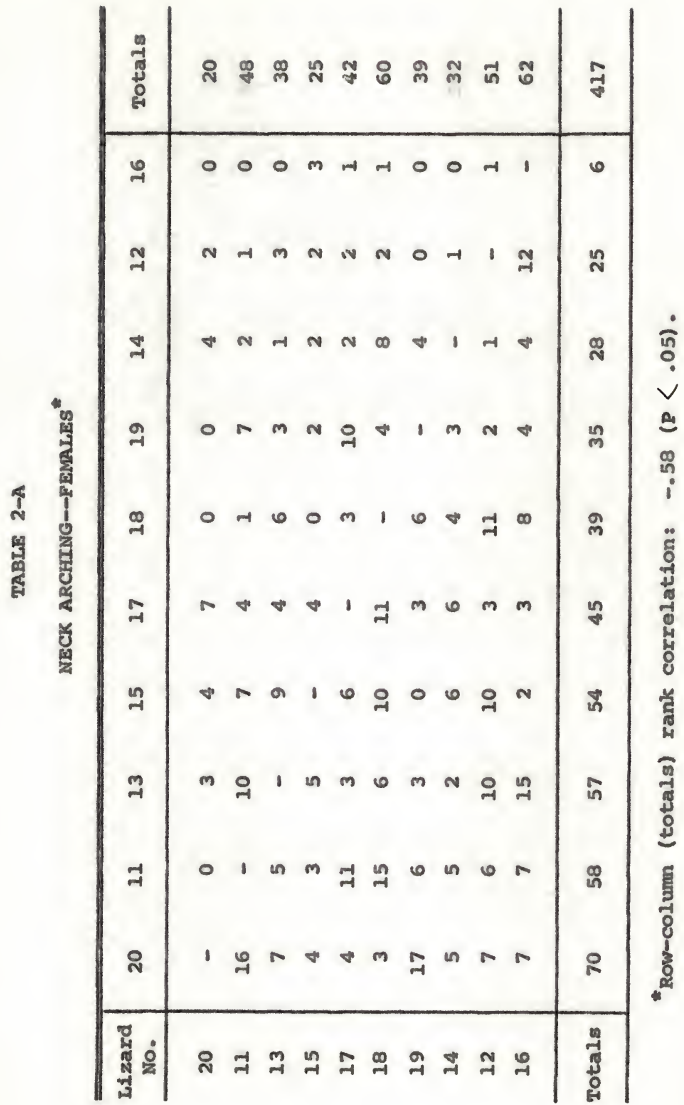




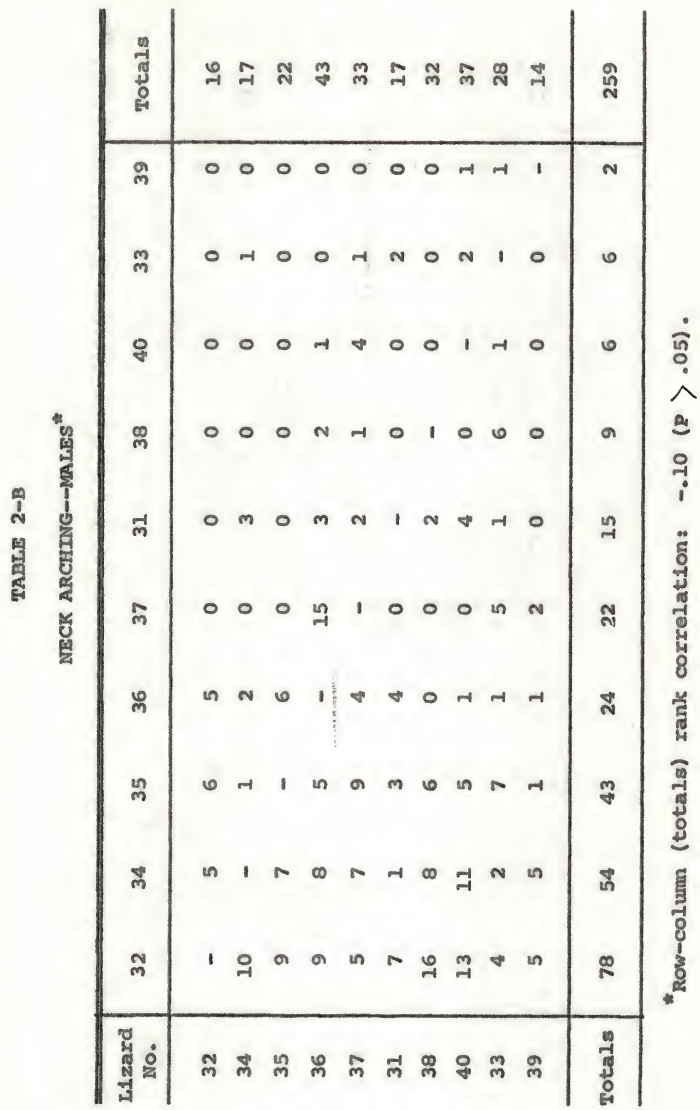




\section{TABLES 3-A AND 3-B}

Tables $3-A$ and $3-B$ indicate the number of tail vibrations made by the lizard numbered in the row across the top toward the lizard 11sted in the column at the left. Totals at bottom indicate number of times vibrations made; at right, number of times vibrations received. 


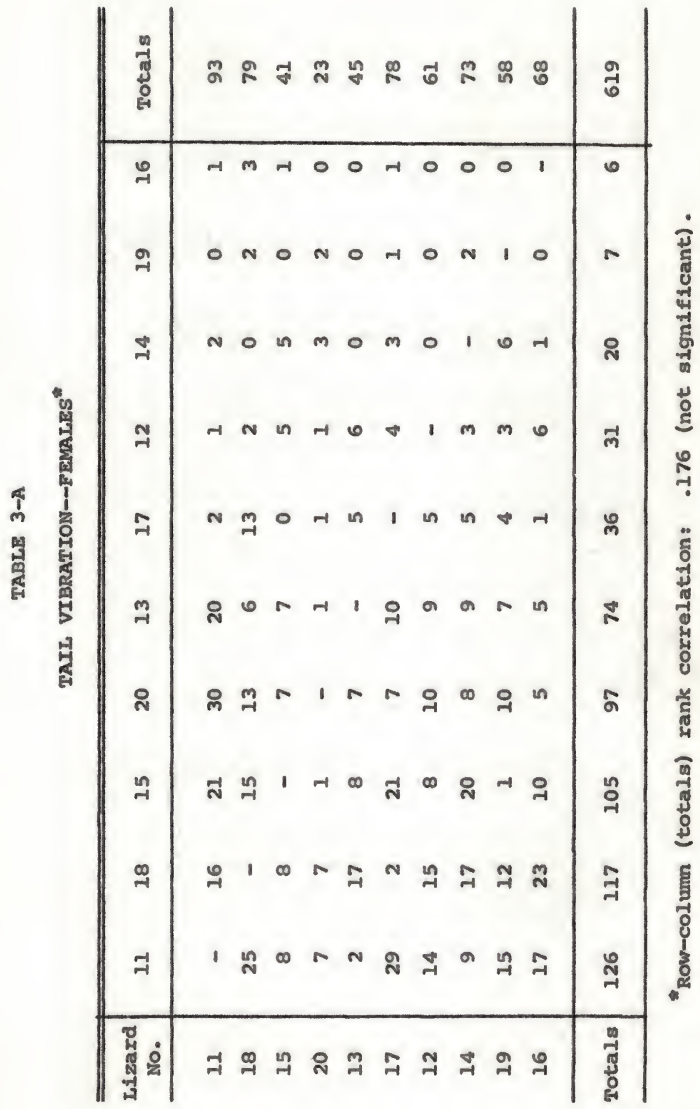




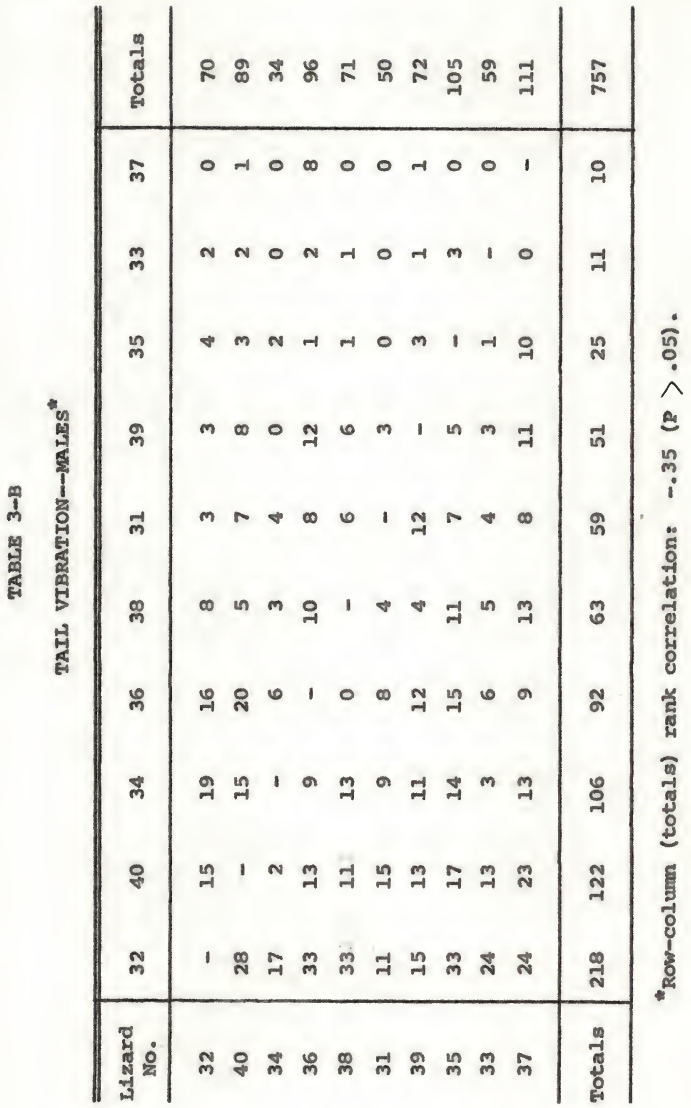




\section{TABLES 4-A AND 4-B}

Tables 4-A and 4-B Indicate the number of touches made by the lizard numbered in the row across the top toward the 11zard listed in the column at the left. Totals at bottom indicate number of touches made; at right, number of touches received. 


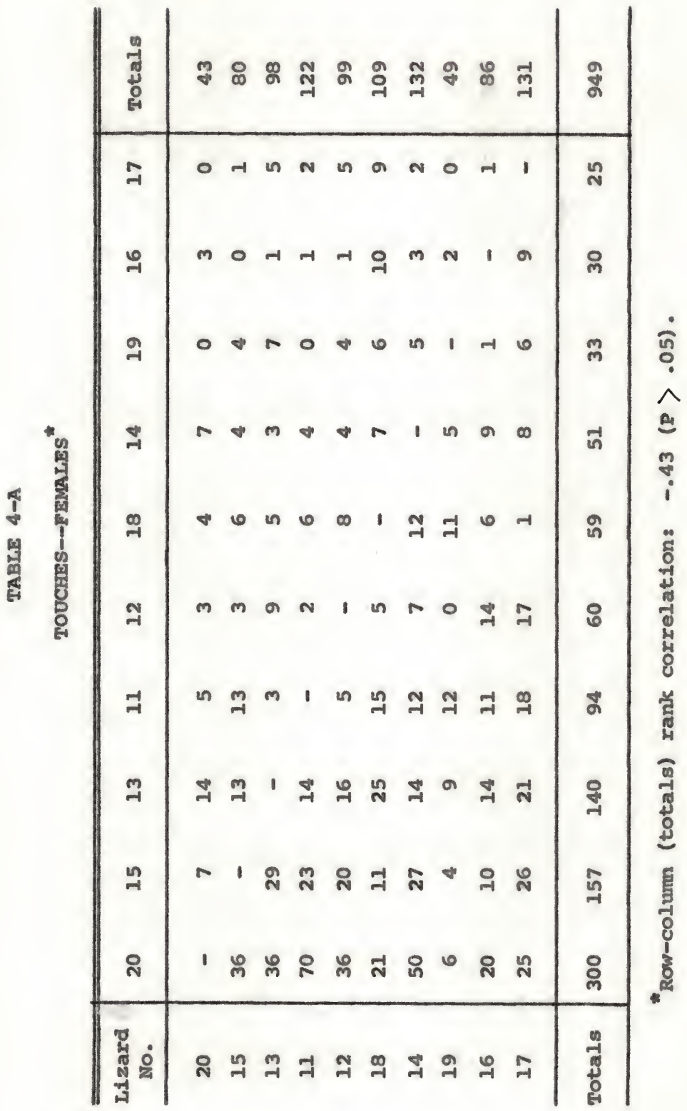




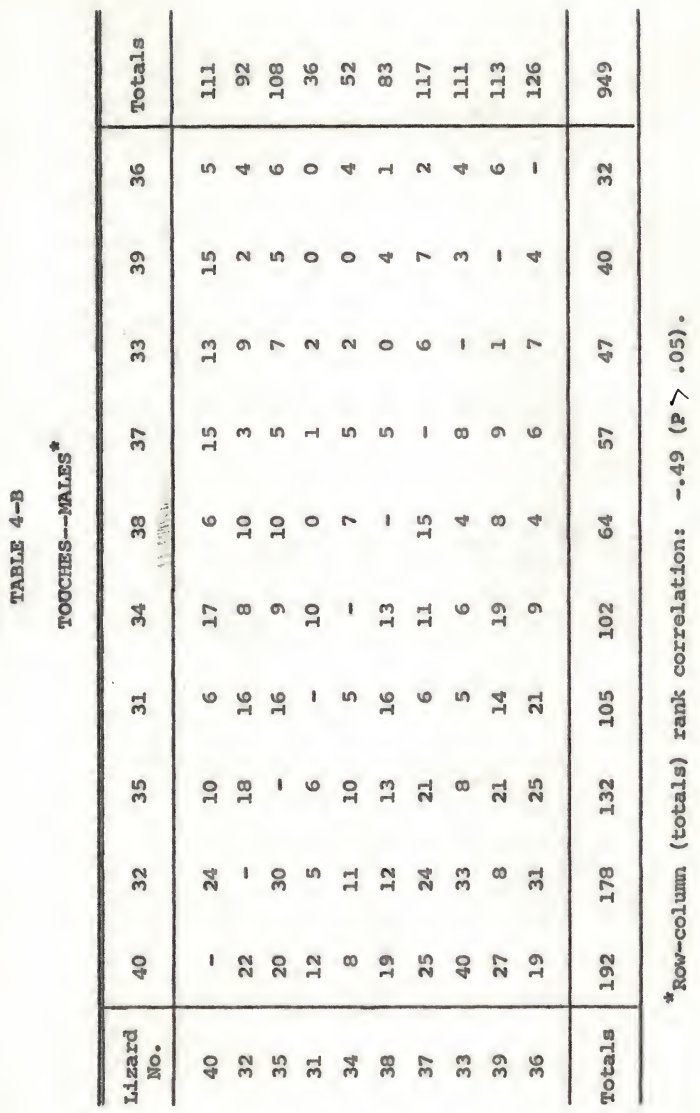




$$
-40-
$$

\section{TABLES 5-A AND 5-B}

Tables $5-\mathrm{A}$ and $5-\mathrm{B}$ indicate the number of bites made by the lizard numbered in the row across the top against the lizard 11sted in the column at the left. Totals at bottom indicate number of bites made; at right, number of bites received. 


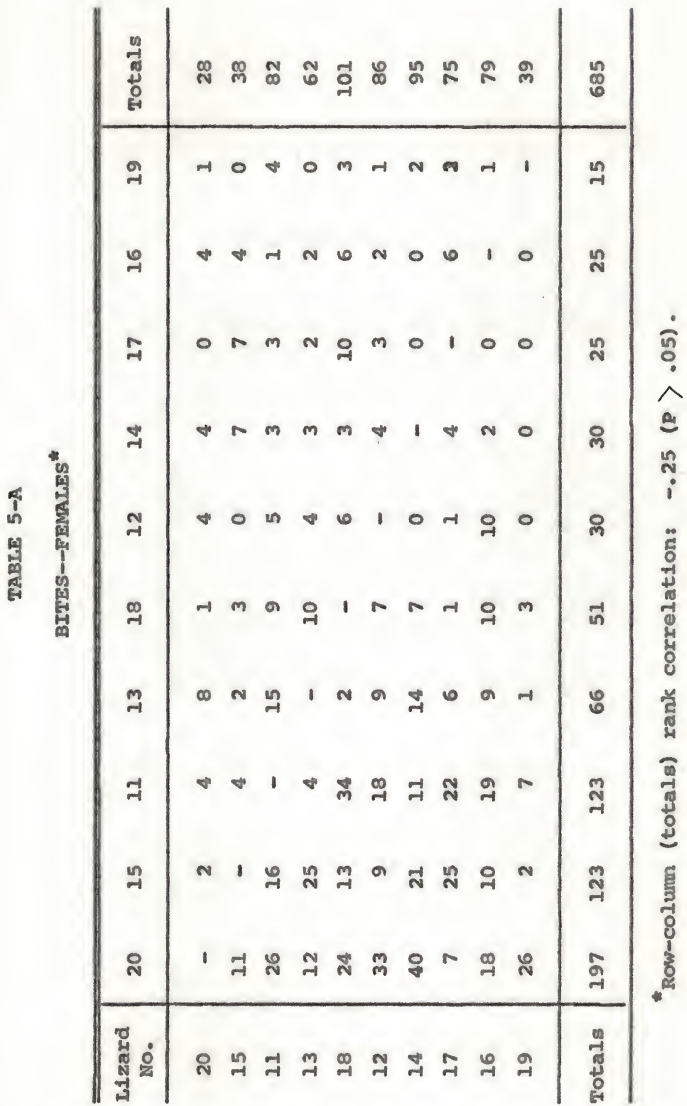




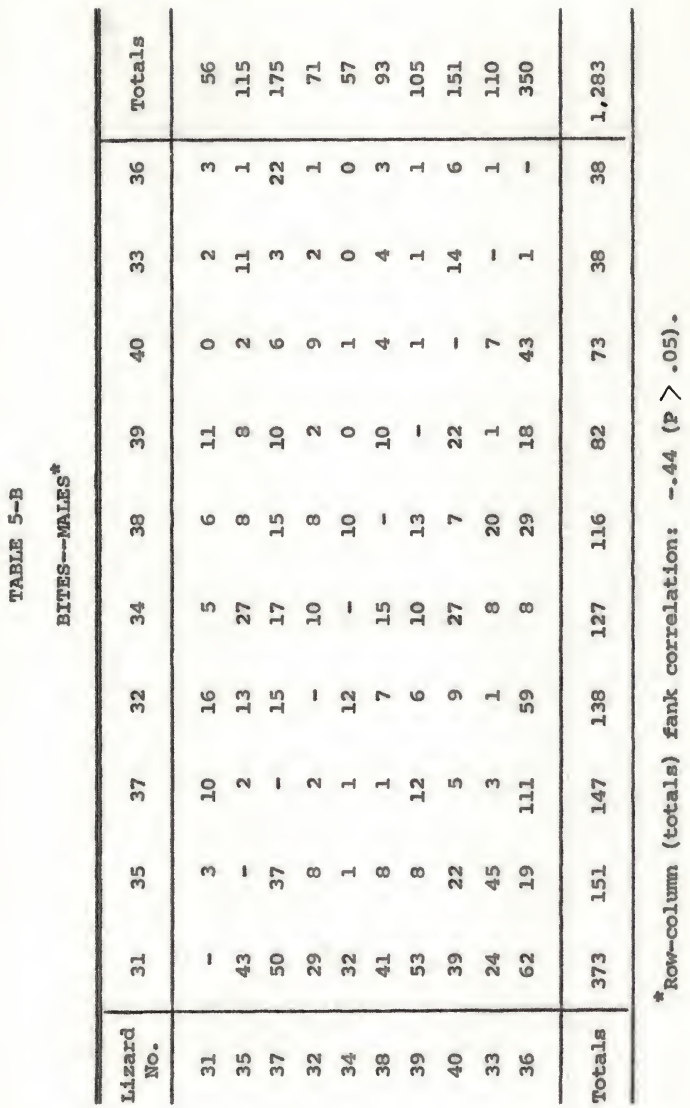




\section{TABLES 6-A AND 6-B}

Tables $6-\mathrm{A}$ and $6-\mathrm{B}$ indicate the number of times tail-waves were made by the lizard numbered in the row across the top when in the presence of the lizard listed in the column at the left. Totals at bottom indicate number of times tall waves made; at right, number "recelved." 


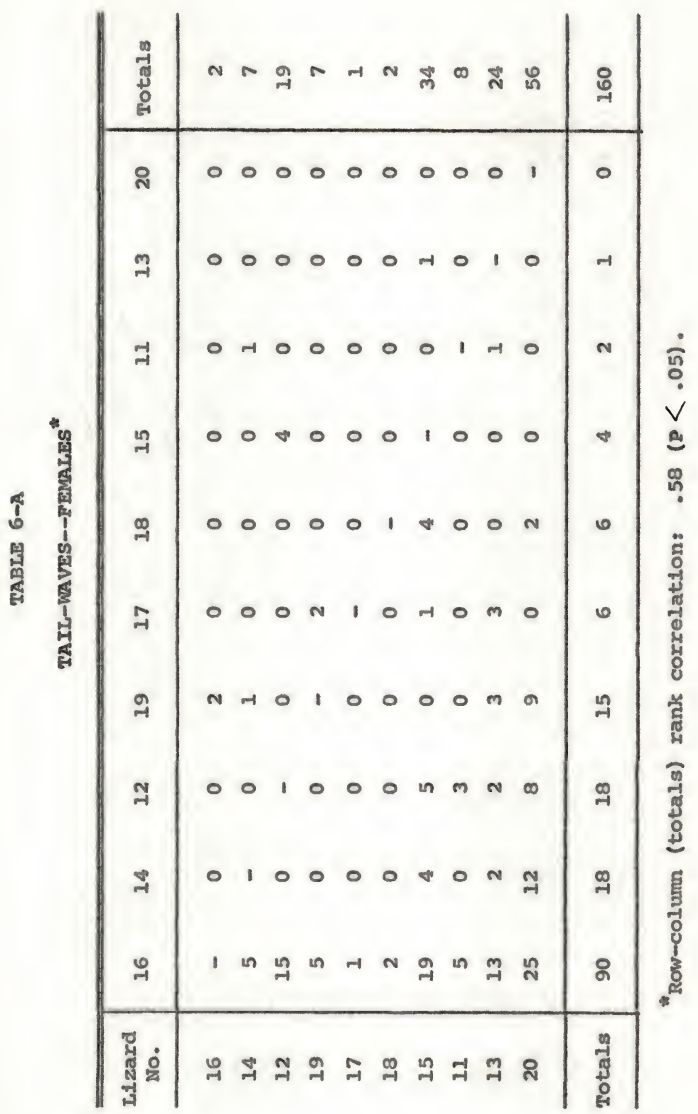




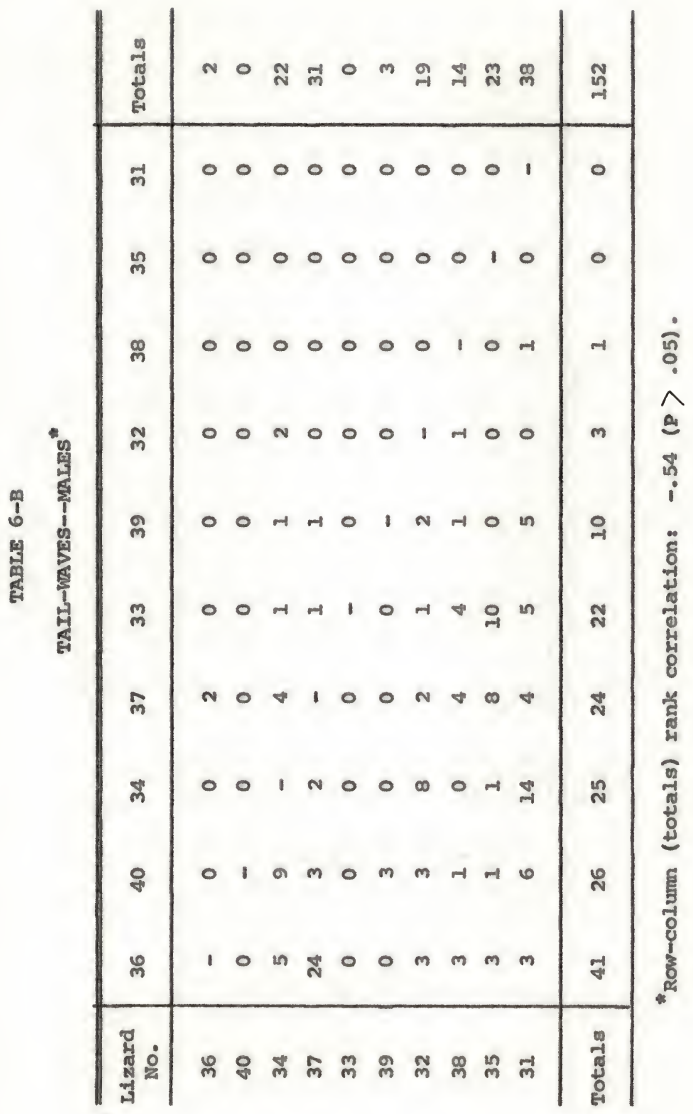




\section{TABLES 7-A AND 7-B}

Tables $7-A$ and $7-B$ indicate the number of movements away made by the 11zard numbered in the row across the top When in the presence of the lizard listed in the columan at the left. Totals at bottom indicate number of movements away made; at right, number made in presence of lizard at left. 


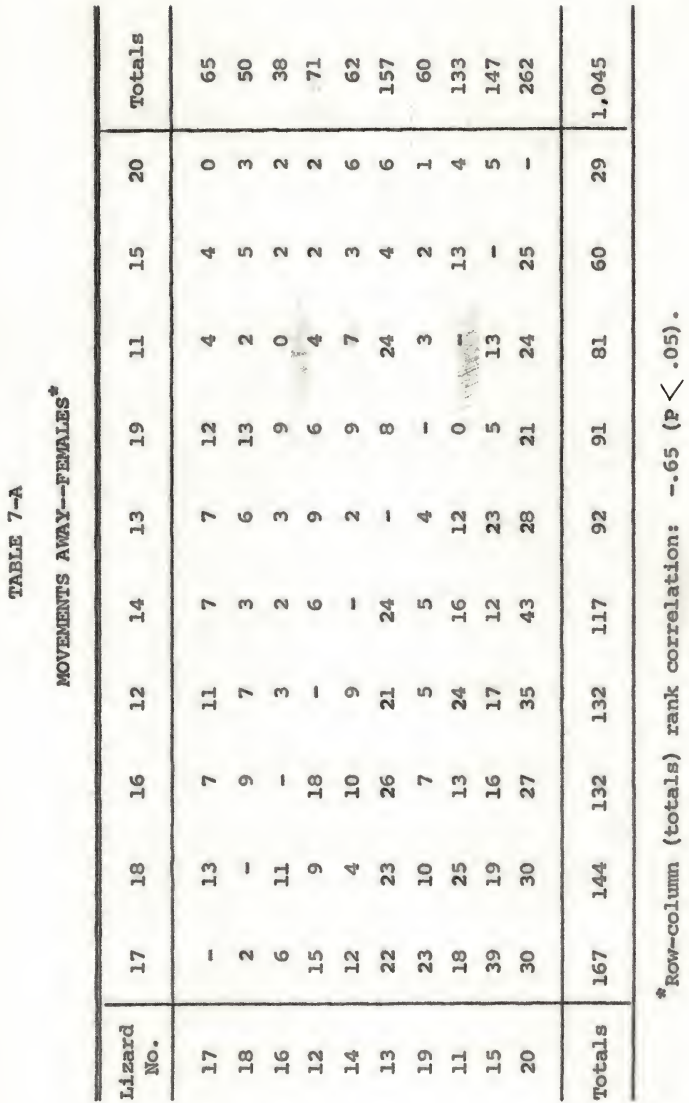




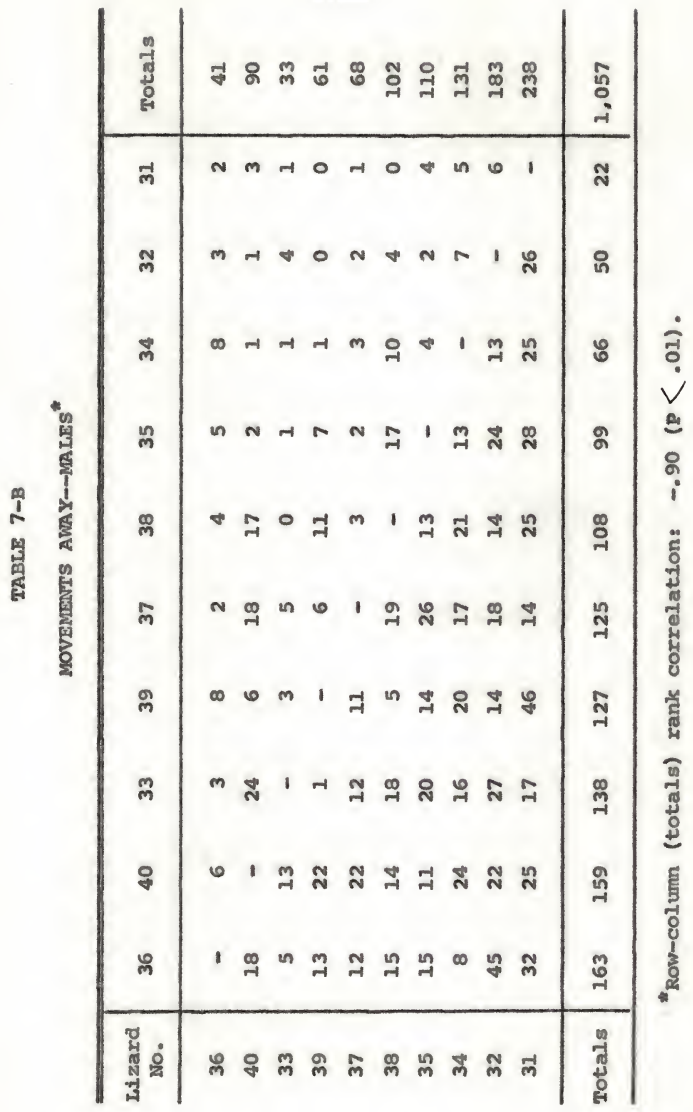




\section{TABLES 8-A AND 8-B}

Tables $8-\mathrm{A}$ and $8-\mathrm{B}$ indicate the number of retreats made by the lizard numbered in the row across the top when in the presence of the lizard listed in the column at the left. Totals at bottom indicate number of retreats made; at right, number made in presence of lizard at left. 


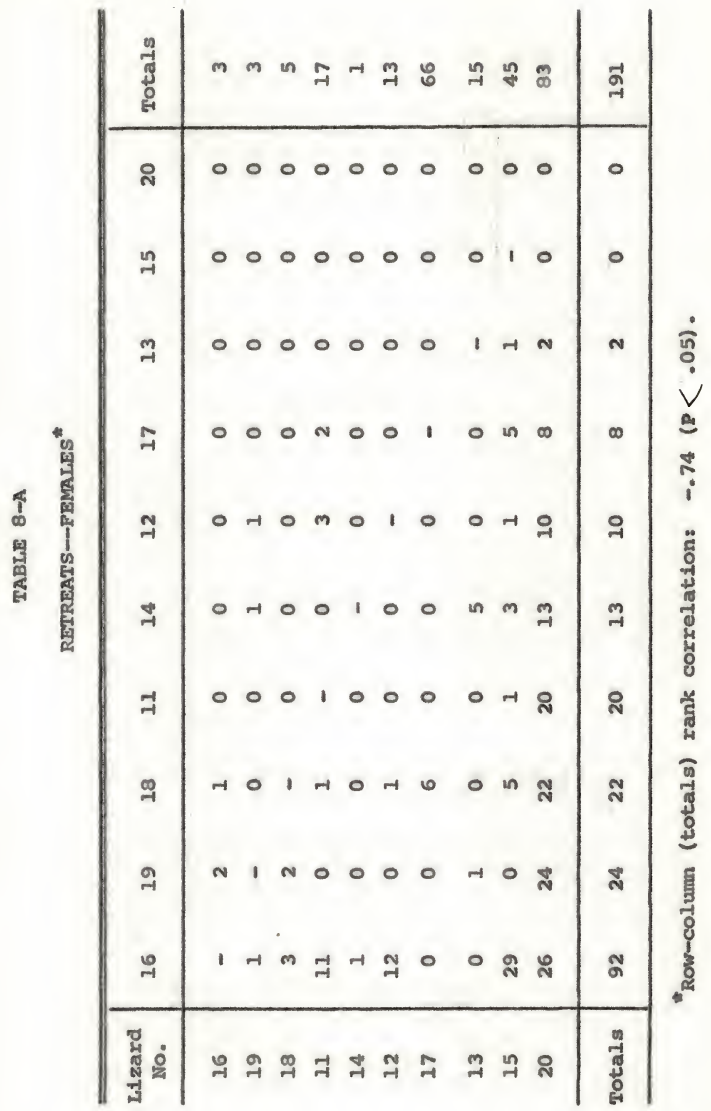




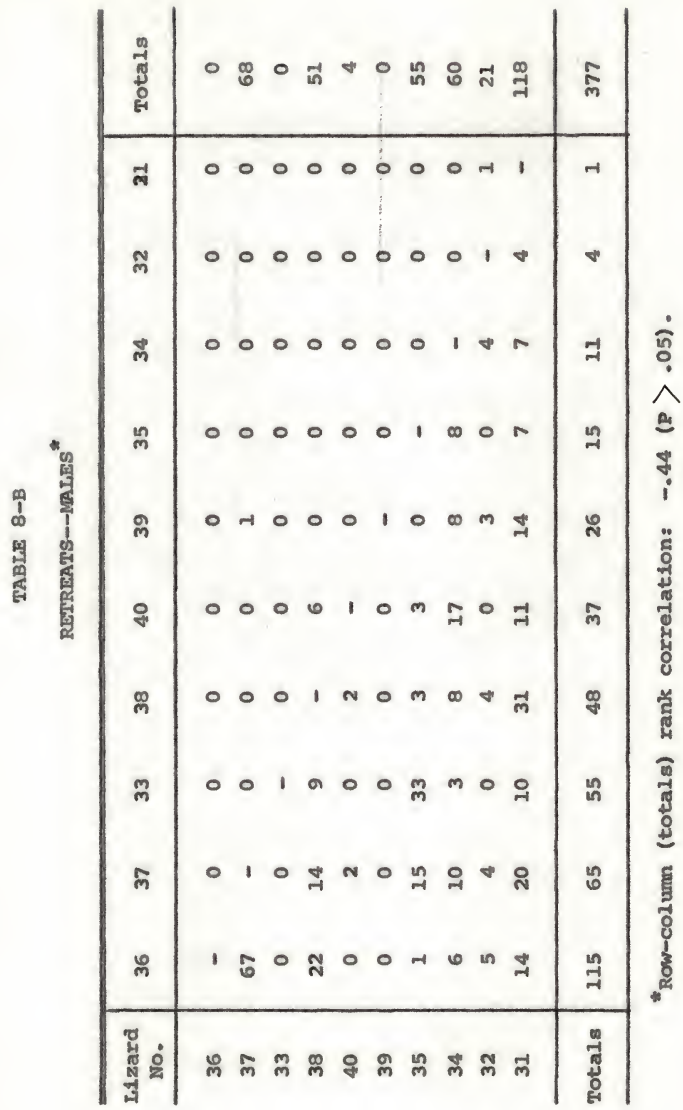




\section{TABLES 9-A AND 9-B}

Tables $9-A$ and $9-B$ indicate the number of unclassiffed movements made by the lizard numbered in the row across the top when in the presence of the lizard listed in the column at the left. Totals at bottom indicate number of unclassified movements made; at right, number made in presence of 11zard at left. 


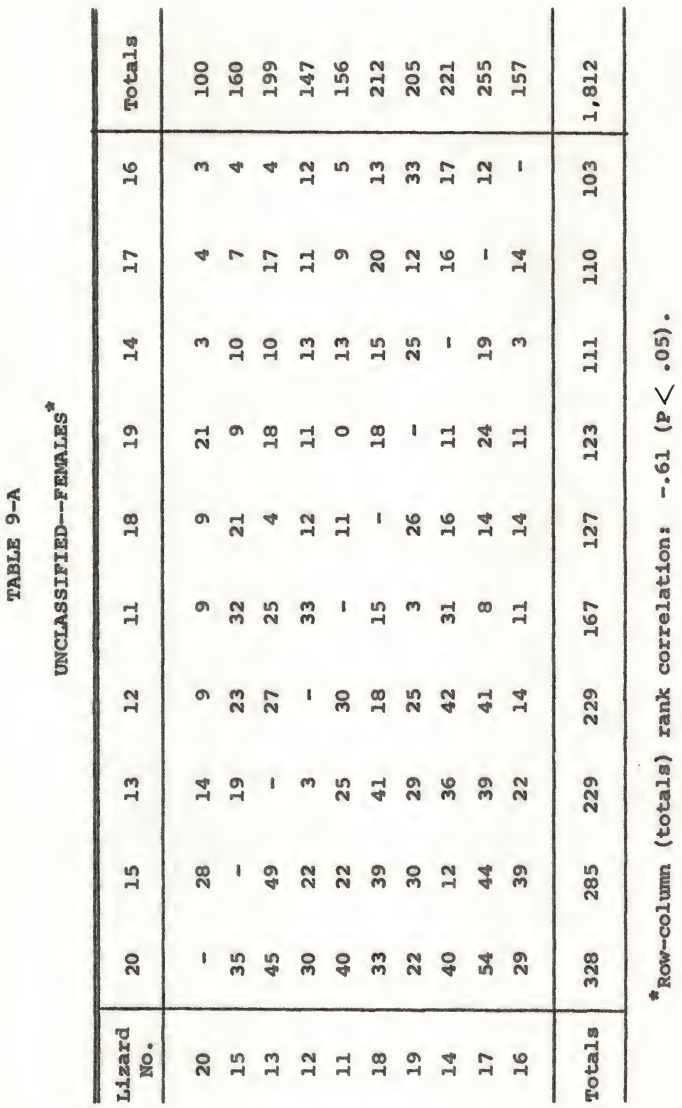




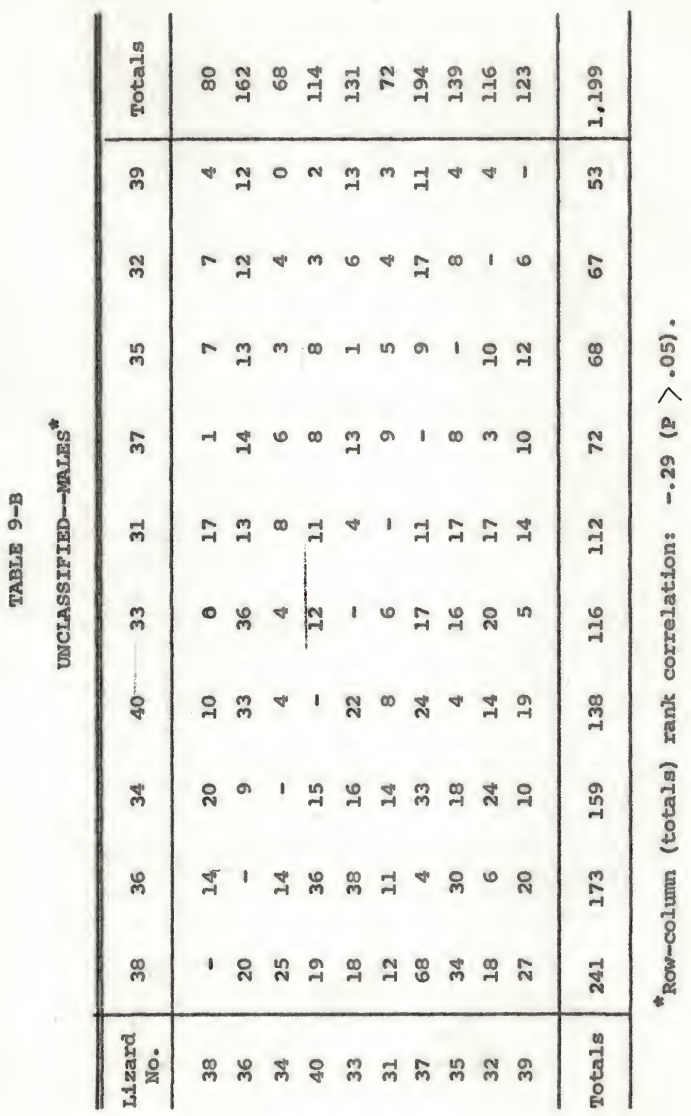




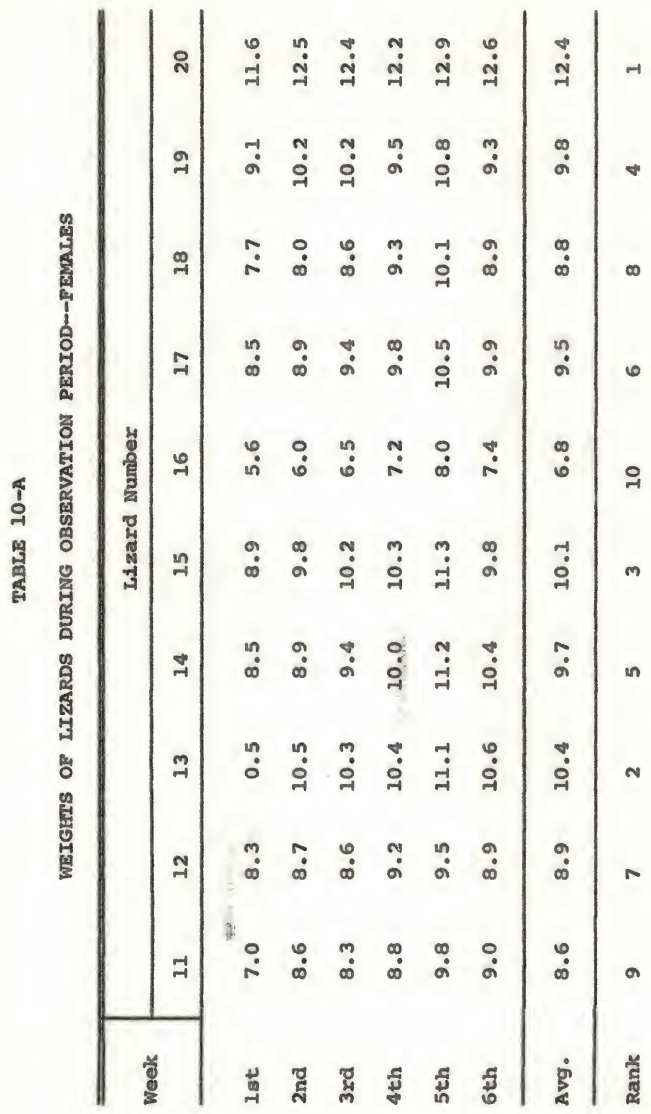




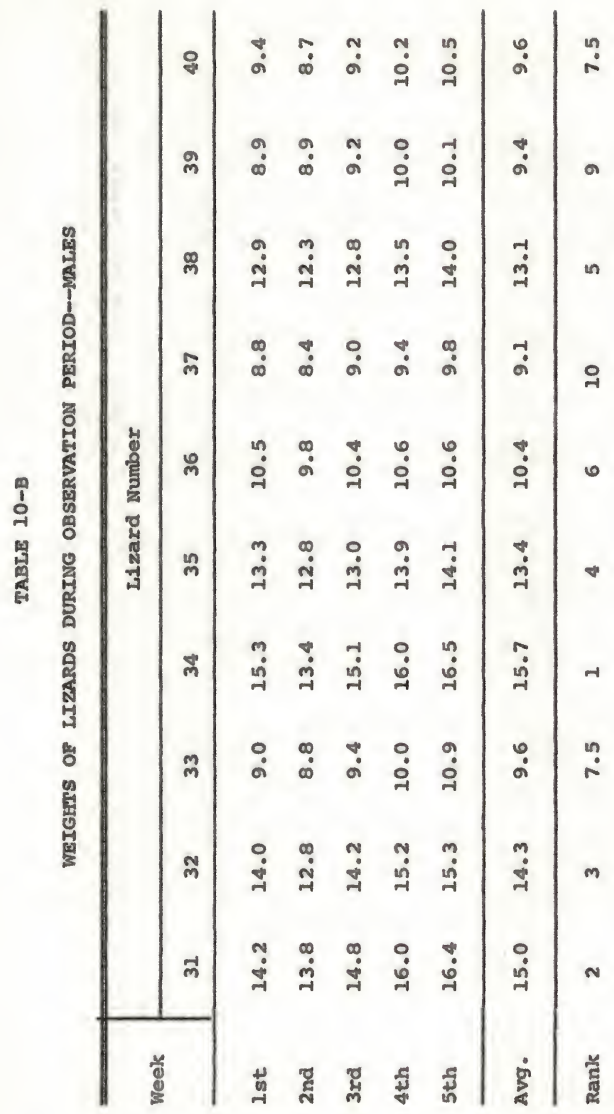


TABLE 11

TOTAL CONTACTS FOR EACH CATEGORY

\begin{tabular}{|c|c|c|c|c|}
\hline & \multicolumn{2}{|c|}{ Females } & \multicolumn{2}{|c|}{ Males } \\
\hline Approach & 1.200 & & 1,414 & \\
\hline Neck Arching & 417 & & 259 & \\
\hline Tail Vibration & 619 & & 757 & \\
\hline Touch & 949 & & 949 & \\
\hline Bite* & 685 & & 1,283 & \\
\hline Total Aggression & & 3,870 & & 4,662 \\
\hline Tail-waving & 160 & & 152 & \\
\hline Movements Away & 1,045 & & 1,057 & \\
\hline Retreat & 191 & & 377 & \\
\hline Total submission & & 1,396 & & 1,586 \\
\hline Unclassified & & 1,812 & & 1,199 \\
\hline TOTAL CONMACTS & & 7.078 & & 7,447 \\
\hline
\end{tabular}

"Difference is significant to 5 per cent level (MannWhitney U-Test). 


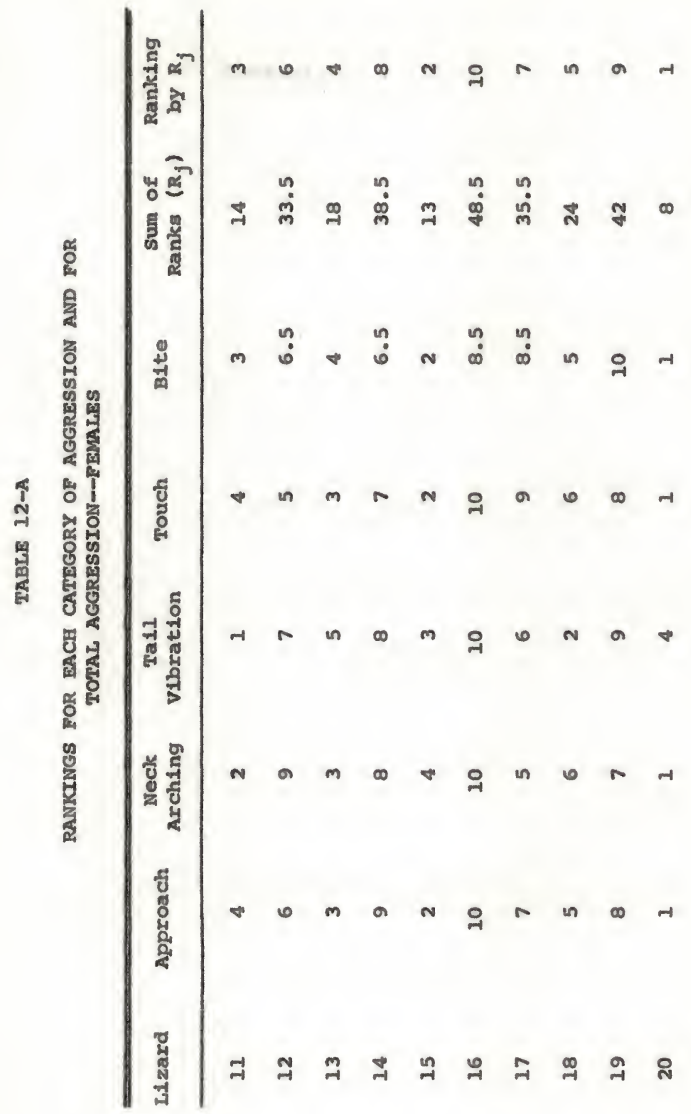




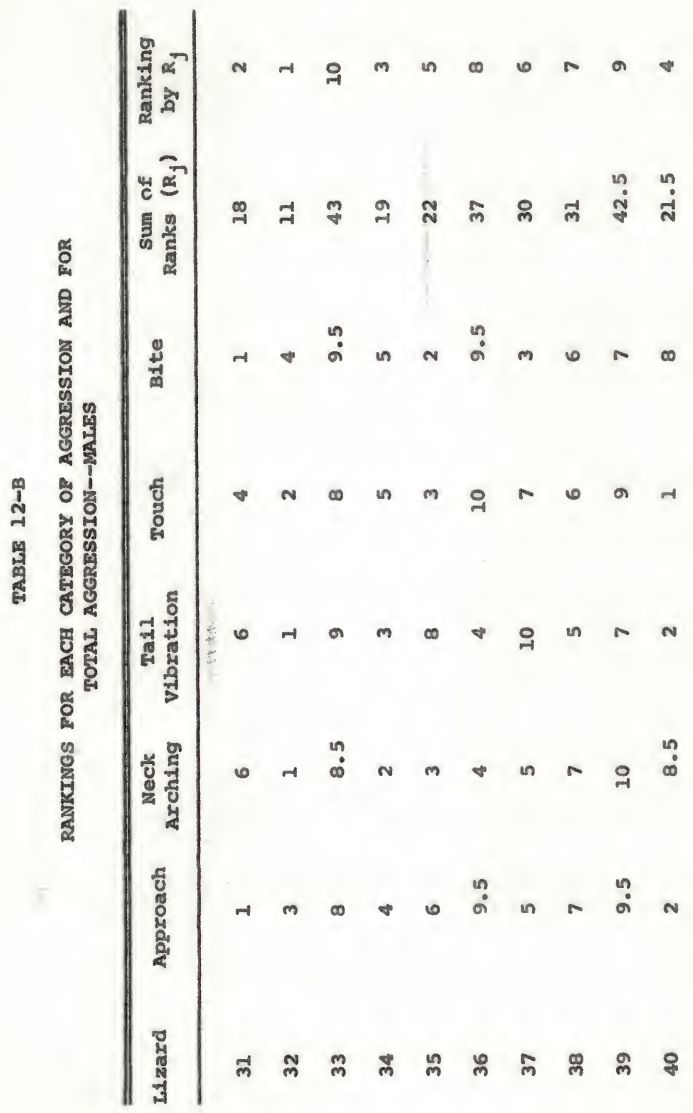


TABLE 13

RANKINGS FOR EACH CATEGORY OF SUBMISSION AND FOR TOTAL SUBMISSION

\begin{tabular}{lccccc}
\hline Lizard & $\begin{array}{c}\text { Tail } \\
\text { Waving }\end{array}$ & $\begin{array}{c}\text { Movement } \\
\text { Away }\end{array}$ & Retreat & $\begin{array}{c}\text { Sum of } \\
\text { Ranks }\left(R_{j}\right)\end{array}$ & $\begin{array}{c}\text { Ranking } \\
\text { by } R_{j}\end{array}$ \\
\hline \multicolumn{7}{c}{ Aemales } \\
11 & 8 & 8 & 4 & 20 & 7 \\
12 & 2.5 & 3.5 & 6 & 12 & 3 \\
13 & 9 & 6 & 8 & 23 & 8 \\
14 & 2.5 & 5 & 5 & 12.5 & 4 \\
15 & 7 & 9 & 9.5 & 25.5 & 9 \\
16 & 1 & 3.5 & 1 & 5.5 & 1 \\
17 & 5.5 & 1 & 7 & 13.5 & 6 \\
18 & 5.5 & 2 & 3 & 10.5 & 2 \\
19 & 4 & 7 & 2 & 13 & 5 \\
20 & 10 & 10 & 9.5 & 29.5 & 10 \\
\hline
\end{tabular}

B. Males

\begin{tabular}{rlrrrr}
\hline 31 & 9.5 & 10 & 10 & 29.5 & 10 \\
32 & 7 & 9 & 9 & 25 & 9 \\
33 & 5 & 3 & 3 & 11 & 3.5 \\
34 & 3 & 8 & 8 & 19 & 7 \\
35 & 9.5 & 7 & 7 & 23.5 & 8 \\
36 & 1 & 1 & 1 & 3 & 1 \\
37 & 4 & 5 & 2 & 11 & 3.5 \\
38 & 8 & 6 & 4 & 18 & 6 \\
39 & 6 & 4 & 6 & 16 & 5 \\
40 & 2 & 2 & 5 & 9 & 2
\end{tabular}


TABLE 14

RANKINGS FOR UNCLASSIFIED CAYEGORY

\begin{tabular}{|c|c|c|c|}
\hline \multicolumn{2}{|c|}{ Females } & \multicolumn{2}{|c|}{ Males } \\
\hline LLzard & Rank & Llzard & Rank \\
\hline 11 & 5 & 31 & 6 \\
\hline 12 & 4 & 32 & 9 \\
\hline 13 & 3 & 33 & 5 \\
\hline 14 & 8 & 34 & 3 \\
\hline 15 & 2 & 35 & 8 \\
\hline 16 & 10 & 36 & 2 \\
\hline 17 & 9 & 37 & 7 \\
\hline 18 & 6 & 38 & 1 \\
\hline 19 & 7 & 39 & 10 \\
\hline 20 & 1 & 40 & 4 \\
\hline
\end{tabular}


TABLE 15

KENDALC COEFFICTENT OF CONCOROANCE (W)

FOR RAMKINGS AMONG AGGRESSIVE

AND SUBMISSIVE CATEGORIES

\section{พ}

$P<$

\section{A. Females}

\section{Aggression}

$\begin{array}{lll}\text { set } 1 & .871 & .001 \\ \text { Set } 2 & .713 & .001 \\ \text { Set } 1+\operatorname{set~} 2 & .849 & .001\end{array}$

Submission

$\begin{array}{lll}\text { Set } 1 & .701 & .05 \\ \text { Set } 2 & .745 & .02 \\ \text { Set } 1+\text { set } 2 & .695 & .05\end{array}$

B. Males

Aggression

$\begin{array}{lll}\text { set } 1 & .560 & .01 \\ \text { Set } 2 & .557 & .01 \\ \text { set } 1+\text { Set } 2 & .522 & .01\end{array}$

Submisston

Set 1

Set 2

Set $1+\operatorname{set} 2$
.792

.659

.806
.02

.05

.01 
TABLE 16

CORRELATIONS OF RANKINGS * IN AGGRESSION AND SUBMISSION BETWEEN SETS

A. Fernales

Aggression: set $1 /$ set 2

.730

.05

Submission: set $1 /$ set 2

.564

.05

B. Males

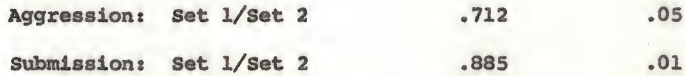
categories.

* Rankings based on sum $\left(R_{j}\right)$ of rankings in individual 
TABLE 17

FREQUENCY OF ALL CONTACTS COMPARED BY SETS

\begin{tabular}{|c|c|c|c|c|}
\hline & \multicolumn{2}{|c|}{ Females } & \multicolumn{2}{|c|}{ Males } \\
\hline & Set 1 & Set 2 & set 1 & Set 2 \\
\hline Approach & 712 & 488 & 633 & 781 \\
\hline Neck Arching & $265^{*}$ & $.152 *$ & 100 & 159 \\
\hline Ta11 vibration & 383 & 236 & 401 & 356 \\
\hline Touch & 484 & 465 & 385 & 564 \\
\hline Blte & $502 *$ & $183^{4}$ & 373 & 546 \\
\hline Totals & 2,346 & 1.524 & 2.256 & 2.406 \\
\hline Ta11-waving & $120^{*}$ & $40^{*}$ & 52 & 100 \\
\hline Movement Away & 558 & 487 & 513 & 544 \\
\hline Retreat & 1.39 & 52 & 148 & 229 \\
\hline Totals & 817 & 579 & 713 & 873 \\
\hline Unclassifled & $657 *$ & $1.155^{*}$ & 638 & 561 \\
\hline
\end{tabular}

"significant difference (5 per cent level or better) for Mann-Whitney U-Test. 
TABLE 18

CORRELATIONS OF RANKTNGS" BETWEEN

AGGRESSION AND SUBVISSION

A. Females

$\begin{array}{lll}\text { Aggression/submission } & -.782 & .01\end{array}$

B. Males

$\begin{array}{lll}\text { Aggression/Submission } & -.645 & .05\end{array}$ categories.

"Rankings based on sum $\left(R_{j}\right)$ of rankings of Individual 
TABLE 19

RANK CORRELATION BETWEEN RAMKS FOR TOTAL" AGGRESSION AND SUBMISSION AND RANKS FOR EACH UNIT OF AGGRESSION AND SUBMISSION

\begin{tabular}{|c|c|c|c|c|}
\hline & \multicolumn{2}{|c|}{ Females } & \multicolumn{2}{|c|}{ Males } \\
\hline & $r_{\mathrm{s}}$ & $\mathbf{P}<$ & $\mathbf{r}_{\boldsymbol{g}}$ & $P<$ \\
\hline Aggress1on/Approach & .976 & .01 & .888 & .01 \\
\hline Aggression/Neck Archlng & .855 & .01 & .627 & .05 \\
\hline Aggression/Tail Vibration & .842 & .01 & .576 & .05 \\
\hline Aggression/Touch & .939 & .01 & .806 & .01 \\
\hline Aggression/B1te & .952 & .01 & .664 & .05 \\
\hline Submission/Ta11-waving & .867 & .01 & .818 & .01 \\
\hline Submission/Movement Away & .748 & .01 & .967 & .01 \\
\hline Submission/Retreat & .815 & .01 & .888 & .01 \\
\hline
\end{tabular}
gorles.

"Based on sum $\left(R_{j}\right)$ of rankings for individual cate- 
TABLE 20

CORRELATIONS OF RANKINGS FOR UNCLASSIFIED CATEGORY WITH ALL OTHER CATEGORIES AND WITE TOTAL" AGGRESSION AND SUBMISSION

\begin{tabular}{|c|c|c|c|c|}
\hline & \multicolumn{2}{|c|}{ Females } & \multicolumn{2}{|c|}{ Males } \\
\hline & $x_{s}$ & $P<$ & $x_{s}$ & $\mathbf{P}$ \\
\hline Approach/Unclass1f1ed & .927 & .01 & -.064 & $* *$ \\
\hline Neck Archlng/Unclassifled & .673 & .05 & -.009 & $*$ \\
\hline Ta11 V1brat1on/Unclassifled. & .588 & .05 & .261 & $* *$ \\
\hline Touch/Unclass1fied & .976 & .01 & -.152 & $* *$ \\
\hline BLte/Unclassified & .842 & .01 & -.409 & $* *$ \\
\hline \multicolumn{5}{|l|}{ Total Aggression/ } \\
\hline Ta11-Waving/Unclass1f1ed & -.733 & .05 & .409 & $\star *$ \\
\hline Movement Away/Unclassifled & -.694 & .05 & .297 & *t: \\
\hline Retreat/Unclassified & -.736 & .05 & .406 & $* *$ \\
\hline $\begin{array}{l}\text { Total submission/ } \\
\text { Unclassified }\end{array}$ & -.733 & .05 & .385 & $\#$ \\
\hline gorles. & & & Idual & \\
\hline
\end{tabular}


TABLE 21

CORRELATIONS OF AGGRESSIVE AND SUBMISSIVE CATEGORIES WITH EACH OTHER

\begin{tabular}{|c|c|c|c|c|}
\hline & \multicolumn{2}{|c|}{ Females } & \multicolumn{2}{|c|}{ Males } \\
\hline & corr. & $\mathbf{P}<$ & corr. & $\mathbf{P}<$ \\
\hline Approach/Neck Arching & .855 & .01 & .336 & ๘ \\
\hline Approach/Ta11 Vibration & .782 & .01 & .406 & $*$ \\
\hline Approach/Touch & .939 & .01 & .830 & .01 \\
\hline Approach/Bite & .897 & .01 & .573 & .05 \\
\hline Neck Arching/Ta11 vibration & .758 & .01 & .355 & * \\
\hline Neck Arching/Jouch & .745 & .01 & .273 & * \\
\hline Neck Arching/Bite & .764 & .01 & .445 & $*$ \\
\hline Ta11 Vibration/Touch & .673 & .05 & .479 & 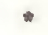 \\
\hline Tail vibration/Bite & .782 & .01 & -.155 & $*$ \\
\hline Touch/Bite & .927 & .01 & .482 & $\bullet$ \\
\hline Ta11-waving/Movement Away & .586 & .05 & .706 & .05 \\
\hline Ta11-waving/Retreat & .670 & .05 & .582 & .05 \\
\hline Movement Away/Retreat & .434 & $\bullet$ & .843 & .01 \\
\hline
\end{tabular}

"Not significant. 
TABLE 22

ACTIVITY RANKINGS* OF ISOLATED FEMALES

\begin{tabular}{cc}
\hline Lizard & Ranking \\
\hline 11 & 2 \\
12 & 10 \\
13 & 3 \\
14 & 5 \\
15 & 1 \\
16 & 7 \\
17 & 8 \\
18 & 6 \\
19 & 9 \\
20 & 4 \\
\hline
\end{tabular}

"Based on frequency of movement into marked quadrants during two fifteen-minute observation periods.

TABLE 23

DISTRIBUTION OF BITES ACCORDING TO

BODY REGION

\begin{tabular}{lrccc}
\hline & Head & Body & Ta11 & Totals \\
Females & 46 & 126 & 329 & 501 \\
Males & 144 & 446 & 679 & 1,269 \\
Totals & 190 & 572 & 1,008 & 1,770
\end{tabular}




\section{DISCUSSION}

In this study the author has attempted to analyze the phenomenon of aggression by indicating different levels of intensities of aggressive activity, different expressions of aggression, and individual differences in aggressive behavior. These and other aspects of the relationships among the experimental animals are emphasized in the following discussion of the individual tables in which the data are presented.

Tables 1 through 9 show the summaries of all individual contacts in aggression and submission. In each table, the 11zards are listed from highest to lowest frequency in the performance of the particular activity. This sequence occurs from top to bottom and from left to right. This sort of table gives a picture of differential aggression and submission since it also shows the number of contacts received by each animal. A comparison of the totals delivered (bottom row) with the totals received (right-hand column), as a row-column rank correlation, should show a negative correlation in aggressive activity is not a random occurrence. Theoretically, aggressive-submissive contacts could range 
from complete randomess to a one-sided hierarchy in which no individual ever shows any aggression toward one ranking above him. In such straight-line hierarchies as that shown by the domestic fowl (Guhl, 1945; Guhl and Allee, 1944) and the jungle fowl (Banks, 1956), the upper right half of this type of chart would have mostly zeros with only a few numbers indicating reversals or peck-order violations. In random aggressive activity one would expect to find high numbers scattered randomly over the table. The relationships of these skinks are obviously neither of these extremes.

Inspection of Tables 1 through 9 shows that most of the higher numbers are concentrated in the lower lefthand part of the table; however, inspection of the upper right shows many instances of lower ranking animals delivering more contacts than are received from higher ranking animals. These exceptions and variations in aggression among the higher ranking Individuals are apparently sufficient to prevent all row-column rank correlations from being significant (and one, Table $3 \mathrm{~A}$, is even positive). Those categories showing a significant negative correlation are approach (male and female), neck arching (female), tail waving (female), movement away (male and female), 
retreat (female), and unclassified (female). It appears from these data that not all categories are equally representative of differential aggression, nor do males and females show differences in the same way. This is supported by a consideration of the data presented in the remaining tables.

In many papers dealing with social hierarchies or dominance-subordinance situations (Schjelderup-Ebbe, 1935; Collias, 1943; Uhrich, 1938; Ginsburg and Allee, 1942; Maslow, 1940; Crawford, 1942; Evans, 1936; Braddock, 1945), the authors do not adequately define the hierarchy or peck-order which they describe or discuss. For instance, they do not suggest where, between the two extremes, random aggression (if such a thing exists) and the rigid completely one-sided type of aggression, the peck-order begins. Should there be an arbitrary line drawn in this apparent contimum of aggressive activity? Masure and Allee (1934) apparently drew one line when they distinguished between the "peck-right" and the "peck-dominance" type of hierarchy, though the line is not a sharp one. In their peck-right type the subordinate birds do not generally peck birds above them in the peck order, whereas in the peck-dominance type there is a more or less asym- 
metric peck exchange. Tinbergen (1953) uses a criterion of learning in which each animal learns "its place," thus reducing the amount of actual fighting. Haubrich (1961) implies that a significant correlation between totals given and totals received (row-column rank correlation) relates his data to the peck order. If the last standard is used in this work, then certain categories strongly resemble the hierarchical relationship while others are much less clear. However, it is probably best not to attempt to establish too rigld a set of criterla for the peck order; and, because of the many differences in ecology, types and levels of aggression, and possibly in origin of aggression, it may be more practicable to judge each case by slightly different standards. This situation is somewhat analogous to recent discussion (Van Valen, 1960; Reed, 1960; Simpson, 2960) as to whether or not certain extinct animals should be considered mamal-11ke reptiles or reptilelike manmals. The definitions are not as important as the existence of enough information to generate discussion and disagreement.

In this study then, on the basis of Tables 1 through 9, it is possible to say that certain expressions of aggression and submis sion present a pattern which 
resembles soclal hierarchies in some animals. This pattern. where present, is best described as a weak peck-dominance type of hierarchy, which was present under the conditions of these experiments. As Lorenz (1935) suggests for such captive groups, there should be no implication of 1 ts existence in nature. Further comment concerning the individual categories as expressions of aggression and submission will be made in the discussions of the remaining tables.

Table 11 shows the total contacts for each category for each sex. These totals are surprisingly similar. The only category which shows a significant difference in freguency between the sexes is the bite category. The fact that this category shows the one significant difference is In accord with the Impressions of the observer during the observation period. Biting among the males was more frequent and more viclous than among the females. It terminated the contact among females much more quickly than among males, the bites of which frequently occurred in rapid exchanges amid flurries of activity. Since male lizards are generally consldered to be the more aggressive, the more belligerent, and the more active of the sexes (Fitch, 1954; Greenberg and Noble, 1944), It might be expected that 
this ultimate in aggressive behavior, the bite, should show the greatest difference. However, it is somewhat surprising that none of the other aggressive categories shows a significant difference and the question might be raised as to whether they represent lower levels of aggression.

Table 11 also shows the relative frequency for each aggressive category. When looked at from this view, the table shows the order of categorles from the most to the least frequent as follows:

\section{Females: Approach, Touch, Bitẹ, Tail Vibration, Neck Arching \\ Males: Approach, Bite, Touch, Tail Vibration, Neck Arching}

The only difference in the two orders is brought about by the mach-increased frequency of bites among males. Can this 1ist, then, represent an arrangement by levels of aggression? It is the belief of the writer that, with certain reservations, it does. As stated above, the bite is the most severe form of aggression among these animals. since the touch is an actual physical contact (and was frequently followed by a bite) that almost always elicited a response by the other 1izard, it should be considered the next most severe level. Thus, of the first three, the approach is the lowest level of aggression and occurs with the 
greatest frequency in both sexes. The position of the other two categories is not so clear. They occur with less frequency than the bite, but they certainly are not higher levels of aggression than the bite. The question arises as to whether or not one or both of these represent a challenge in this animal. This will be considered elsewhere.

It is also seen in Table 11 that the three submissive categories occur in the same order of frequency for both sexes. The greatest apparent difference occurs in the retreat category. The greater number of retreats on the part of males can best be explained by the greater aggressiveness and intensity expressed in their contacts. Tables 12, 13, and 14 summarize the rankings for all categories of aggression and submission and the unclassified category. Tables 12 and 13 also show the sum of ranks $\left(R_{j}\right)$ for aggression and submission and the ranking based on this sum. It is the final ranking based on the "Ry" that is referred to as "total aggression" or "total submission" rankings respectively in this paper.

The aum of ranks $\left(R_{j}\right)$ is used in the procecture for calculating the Kendall coefficient of concordance (W) which 1s shown in Table 15. There was no significant change 
in $W$ between Sets 1 and 2 as these and the $W$ for the total observations (Set 1 plus Set 2) were all significant. The choice of the Kendall coefficient of concordance (W) here is based on the occurrence of more than two sets of rankings in both aggressive and submissive categories and its usefulness as a measure of the relation among these several sets of rankings. It merely indicates in this case that there is a correlation among the several rankings but shows nothing concerning what is responsible for the correlation. It is the conclusion of the observer that the element which is common to the group of five categories is aggreesion and that the element which is common to the group of three categories is submission. It was obvious during observations that such things as bites, touches, and approaches were frequently stimulating submissive responses. The role of the tail vibration and the neck arching was mach less obvious to the observer. Since these two categories contribute two-fifths of the data to the computation of w.. it seems reasonable to conclude that there are definitely some elements of aggression involved. This conclusion agrees with the original observations and assumptions upon which the observer based his recognition of supposedly aggressive actions. 
The information in Table 16 indicates that there was no significant shift in rankings for aggression or for submission between set 1 and set 2. This simply means that the lizards, and possibly the observer as well, were consistent in their behavior for these two sets, which were separated by a two-week period. Although this indicates that the relationships were the same in the two sets, it still does not show whether the consistency of the two sets was due to learning and individual recognition which carried over to the second or whether it was dile to individual differences which might have prevailed regardless of the length of separation. Table 17 was prepared as an effort to shed some light on this. It shows the frequency of each category of aggression and submission and the unclassified category for each set. For the males, there is no significant difference in frequency and all variations are not in the same airection. For the females, all variations except in the unclassified category are in the same direction, namely, a decrease. Furthermore, three of these and the unclassified are significantly different. This suggests that some learning or individual recognition did occur. As indicated above, the position of neck arching as an aggressive category is not clear, and this is true of its significance here. It will be discussed elsewhere. 
Another category showing a significant reduction in frequency in the second set is the bite. In aubmissive categories, tail waving is the only one to show such a recuction. If the subnissive animals of the pair matings recognized certain aggressive animals andor learned from their prior experiences, this could explain earlier responses to lower level contacts which would thus reduce the number of bites. It might also reduce the frequency of tail waving, since this seems to be a response of lower-level than movement away or retreat. Since the differences in the above categories show statistical significance, this gives strong support to the suggestion that at least some learning or individual recognition did occur. But even in the figures that lack statistical significance, there is further evidence for this idea. Every category (except unclassified) has a recuced frequency in the second set. We would not expect such uniformity of direction if the frequencies were randomly distributed, so prior experience must be a factor here. There was no such uniformity anong the males; in fact, most of the categories show an increase in frequency. There is no indication in these figures that the males show learning or recognition; however, the greater aggressiveness, pugnacity, and activity 
and possibly the somewhat looser relationship among males could conceal this.

The striking increase in the unclassified category among females is aifficult to explain. It is possible that the energjies of the 1izards were in part taken up with random movements which could not be called aggression or submission or that because of prior experiences of the 1izards, there were included in unclassified contacts aspects of aggression and submission too subtle for the observer to recognize. This relationship was not the same among the males, as they showed an insignificant decrease among unclassifled contacts.

Whereas this study has been concerned with the nature of aggression, it does not diminish the importance of the submissive categories, which have a distinct reality by thenselves. Although the observer may have used each type (aggressive or submissive) of category as an aid in the recognition of the other, ranking by total submission could stand alone as an indicator of aggression among these animals. This is true because rankings by total submission have a significant negative correlation with rankings by total aggression, as shown in Table 18. These submissive categories may in some ways be even more realistic than 
aggressive categories, for they indicate a recognition of aggression on the part of the lizard. What the animal actually recognizes may not be visible to the observer. but the submissive reaction of the animal is.

The results seen in Table 19 were compiled in an effort to see if certain categories of aggression or submission contributed a disproportionate share to the rankings for total aggression or total submission. Thus, we have a comparison of the whole with each of its parts. All correlations, of course, are significant, but it should be noted that the three highest correlations in aggression for each sex are with approach, touch, and bite. This is consistent with other data presented and with the general Impressions of the observer concerning the relationship of these three aggressive categories and the other two. The rank-relationship of the unclassifled category with all other categories and total aggression and submission is shown in Table 20. For the fenales, every comparison with aggression has a significant positive correlation, While every comparison with submission has a significant negative correlation. For the males, the airection of correlation is reversed in all but one category, but none is significant. If the unclassified is unblased and truly 
represents no aggression or submission, one would expect no pattern of correlation with elther group of categories. But with the females the pattern is as if the unclassified is an aggressive category itself. One explanation for this is that the observer, in his conservative appraisal of pair-mate contacts, included in unclassified much that should have been called aggression. If this is true, then the absence of such a correlation with the males indicates that the observer "learned" to discriminate between these contacts better after 112-1/4 hours of observations with the females. Whereas this might have reduced the frequency of aggressive contacts recorded for the females, the relationship among the categories remains the same, as Table 20 indicates for the females. When the Kendall coefficlent of concordance (W) was used (Table 15), there was a significant correlation shown by each sex as discussed above. However, Table 21, showing the correlations of individual categorles with each other, presents a different picture, especially in aggression. In females, every aggressive category is significantly correlated with every other, while among the males, only two such correlations are significant, and the average for all is not significant. This was at first quite puzzling, especially since $W$ is supposed to show essentially the same thing (Siegel, 1956, p. 229) as the average of all paired cor- 
relations, However, an analysis of the rankings of individual animals in each pair of categories reveals a probable answer to this puzzle. This analysis shows that three animals differ in their paired rankings by five or more positions more frequently than any other animals. Ilzards No. 31. No. 36 , and No. 40 shifted five or more positions in ranking four, six, and six times respectively. Such changes in rankings by just a few animals would have a strong effect on the degree of correlation between pairs of rankings. Since the techntque for calculating the Kendall coefficient of concordance uses the rankings in each category only one time, as well as the sum of these rankings, the shifts described above are not effective. In other words, W gives an over-all picture of the several rankings,which is belleved to represent a "contjnulty" of effect by the element of aggression. Individual rank correlations in this case bring out certain individual variations or exceptions to the over-all picture, which probably help to reduce somewhat the value of $w$. There were no such individual exceptions in aggression among females. The particular relationship among these 11zards may help to point out a "weakness" in the use and interpretation of $W$ that could be of irmortance in certain types of correlations. 
The smaller number of categories in submission perhaps prevents a similar picture to that in aggression in Table 21, or else the animals do not vary as much in their submissive actions. The only correlation that is not significant (W is signiflcant for each sex - Table 15) is that between movement away and retreat for females. One would expect these two to have the closest relationship. A check of the individual animals reveals that No. 17 and No. 19 change ranks by six and five positions respectively, and thus contribute enough to the calculations to prevent a significant correlation. Possibly these two animals have different "thresholds" in their reactions to aggression. No. 17, ranking first in movement away. dropped to seventh in retreats. Inspection of Tables $4 \mathrm{~A}$ and $5 \mathrm{~A}$ reveals that No. 17 ranks second in touches received and sixth in bites received. This animal may have responded guickly to touches by moving away and thus generally failed to receive bites from which it might have retreated. On the other hand, No. 19 ranks low in all aggressive categories given or received and high in only one submissive category. retreat. Therefore, this animal must have been relatively inactive, but with a quick threshold of response (in the form of a retreat) to early signs of aggrestion. This de- 
duction is in accord with the observer's own memory of the individual.

In the discussion above of Tables 11 and 17 , reference was made to the relationship between approach, touch, and bite on the one hand and neck arching and tail vibration on the other. There seems to be a consistent difference between these two groups. An examination of Tables 11 and 17 reveals that the frequence of each member of the first group is higher than that of each member of the second group. In Table 19 the corralations involving each member of the first group are higher than any in the second. In Table 21 those correlations between members of the first group above are higher than any other correlations. All of these relationships are true for both sexes. Neck arching and tail vibration have here been considered as two contributors (categories) to the over-all picture of aggression. But might they be more than this? The question arises as to whether or not one or both of these categories might represent a challenge in this animal, comparable, for instance, to the challenges described for Anolls and other Iguanidae (Evans, 1936; Greenberg and Noble, 1944; Noble and Bradley, 1933, Petit, 1928). During the observations there were times when neck arching and tall vibration 
appeared to be "preliminaries" for other aggressive activity. But this was not consistently so. There were times when the observer got the impression that both activities, especially tail vibration, occurred as a "disturbance" (defense posture?) concomitant to aggressive activity. or as a reaction (but not submissive) to aggression. For instance, there were numerous occasions when both animals vibrated their tails after separation from a particularly vigorous contact. Neck arching is associated with still another type of activity in this animal, feeding. It is a position almost always assumed just before the skink lunges for an item of food, In the laboratory or in the field. Many times the lizards arched their necks at each other as they seemed to be maneuvering for an advantageous position. This posture seems to be associated with aggression, but is not necessarily involved as a part of a particular seguence of aggressive activity. Since neither of these actions consistently occurred before the approach, touch, or bite, these explanations for tail vibration and neck arching are better supported by the data than is the suggestion that one or both are challenges.

When a correlation is made between rankings for average weight (Table 10) and rankings for over-all 
aggression (Table 12), the correlation for females is found to be .48 , which is not significant; the correlation for males is .69 , significant at the 5 per cent level. Differences in weight in both sexes can be thought of as representing differences in age or physlological condition. In the males these differences are considered to be factors which affect the relationships of the animals in aggression. This probably is not the case for females. But in the more vigorously expressed aggressive activities of the males, 1t can be said that the heavier 11zards tend to be the more aggressive. Similar conclusions have been reached in studies of crayfish (Bovjberg, 1956), 11zards (Carpenter, 1960; Evans, 1936; Fitch, 1940), chickens (Schjelderup-Ebbe, 1922), mice (Ginsburg and Allee, 1942), and primates (Maslow, 1940).

At the conclusion of observations with the females, each animal was observed for two 15-minute periods while 1solated in the same container used for paired observations. The bottom of the container had been marked into four equal quadrants. Every move made by a lizard from one quadrant to another was recorded. The rankings of the females from the greatest to the fewest number of moves is shown in Table 22. The correlation of this ranking 
with that for over-all aggression is .697 , which is significant to the 5 per cent level. This indicates that in the females the most active animals tend to be the most aggressive. This is further evidence that the physiological condition of the individual animal affects the degree of aggressiveness which it shows. It was the opinion of the observer that the same thing would be true for the males, but unfortunately unavoidable circumstances prevented the conducting of such experiments with the males.

At the conclusion of all observations with the males the observer noted some subjective impressions of individual animals. These lizards had such distinct behavioral differences that, after the many hours of observations, each appeared to have its own "personality" (SchjelderupEbbe, 1953; Pardi, 1946). This subject characterization of the male lizards is shown below as recorded by animal number.

31. Occasionally spends falrly long periods in corners, but quite active when moving. Usually follows approach and touch with a quick direct bite.

32. Fairly active. vibrates tail a lot when moving around and when approached or when approaching. When contacting another lizard, has tendency to push and poke rather than bite. Doesn't bite often and when it does 
it is usually a tail nip, but responds to other larger aggressive lizards with a vigorous bite.

33. Spends most of time in corner, though in later observation periods was more active. When approached and/or touched by a lizard its size or smaller, frequently arched neck and bit, but never puxsued. Always moved quickly away when approached, touched, etc., by larger or more aggressive lizard.

34. Very active, but still for long periods only to burst into action. Frequently bites and pursues vigorously. Much of time spent in moving widely, oblivious of other animals, frequently crawling right over them.

35. Arches neck freguently. Moves around moderately but stays still for long periods. Frequently approaches and touches without biting. Defends self by returning bites againgt some lizards but quickly runs from others. Rarely vibrates tail, rarely bitten on tail. (Note: this animal had the shortest tail, having previously lost most of it and regenerated approximately $46 \mathrm{~mm}$.)

36. Moves around moderate amount. Vibrates tail frequently. When pressed, retaliates with a bite before running. Against submissive indivicuals is fairly aggresitive but does not pursue advantages.

37. "The bluffer." Charges close to or into another animal when approached to within a few inches from front or side only. Does not move around much, but more stirred to action by movements of others. Always runs When pressed. Only against No. 36 did it chase, attack, and bite viciously.

38. Large. Moves around constantly seeking escape. Frequently blunders right by other lizards. Vibrates tiil frequently while 
moving. Arches head and bites when it finally notices other lizaxd or when "provoked."

39. Stays in one spot most of the time, rarely moving except when forced by dominant animal. others, it simply snaps at when they disturb it too much.

40. Approaches any animal repeatedly, regardless of how repulsed. Touches with nose but almost never bites, though occasionally vibrates tail.

In the early stages of observations of these skinks, It was observed that a large proportion of the bites were being delivered to the tail rather than the head or body of the recipient. Fitch (1954) had observed that among fighting males of Eumeces fasciatus "most serious wounds were usually in the sacral region or base of the tail or both." Hunsaker (1962) refers to tail-biting as ritualized behavior in Sceloporus and says that it is about the only type of body contact occurring curing fighting. In these observations the location of bites was recorded when possible. The distribution of 1770 bites received, or 89.9 of the total, is shown in Table 23. When these data are subjected to the chi-square test, with the assumption of randomness as to location, the distribution is found to differ significantly (1 per cent level) from random occurrence. In other words, a greater number of bites was received on the tail than might have been expected by chance. 
The significance of the above distribution appears to be related to other behavioral and morphological adaptations of this animal. The survival value of autotomy has been widely discussed for many groups in the animal kingdom. One of the submissive traits described for this animal is tail waving, already described as a slow undulatory twitching movement. This submissive category can be considered a behavioral adaptation which is associated with the morphological one of autotomy, since animals (e.g., predators) do respond to movement and would be attracted to the moving part rather than to the more vulnerable head or body. These two adaptations might be important in intraspecific compet1tion as well as in predator-prey relationships. Table 23 Indlcates that biting might also be related to these two. Although fighting can disrupt the population if it results in frequent deaths, deaths would not occur if most of the bites were directed to the tail.

Intraspecific aggression can serve to disrupt a population. Thus, the adaptive value of strong hierarchies, Which exist in animals such as the jungle fowl (Banks, 1956) and other birds, is in the 11mitation which they place on aggressive activity. Since Eumeces Inexpectatus does not have social organization in the fleld, the 
disruptive effect of Intraspecific strife could be strong. However, the evidence from this study indicates that this disruptive effect is reduced not only by the action of the animal in waving 1ts ta11, not only by the fact that the tail may be "given up" while the animal escapes, but also by the tendency of aggressive animals to bite the tail rather than the body or head.

No assertion is made in this study that Bumeces inexpectatus is a truly social animal. If one accepts the criteria of Allee (1951) that, "aggressive behavior can be regarded as asocial insofar as it acts to prevent. dicrease, or disrupt the integration of vertebrate socleties, and it can be regarded as social insofar as 1t furthers the integration and organization of such soc1eties," then this animal is, in nature, asoclal. In fact, this work, as does Evans' (1936) study of Anolis, emphasizes anti-social behavior, especially of the male. The nature of the contacts is such that they tend to disrupt and disperse rather than to integrate.

This study shows that even solitary lizards which normally display no evidence of territoriality and which. at the most, show only differential aggression in the field, can in pair-matings in a confined and $11 \mathrm{mited}$ space 
display aggressive behavior that resembles hierarchies in some animals. An attempt is made to compare individual expressions of behavior which contribute to the behavioral Whole as well as to the pattern of differential aggression. It shows that there is much individual and some sexual variation in the expressions of aggression and that this variation may be related to a number of different factors. It indicates that even though aggression may intrinsically be disruptive in its intraspecffic expressions, it may at the same time have distinctive adaptive values. 


\section{SUMMARX AND CONCLUSIONS}

1. The Southeastern five-lined skink, Euneces inexpectatus Taylor, displays certain behavioral activities (neck arching, tail vibration, approach, touch, and bite) which are interpreted as aggression, and others (tail waving, movement away, and retreat) which are interpreted as submission. Another activity (unclassified) was not identifiable as either aggression or submission.

2. There are no significant differences between sexes in frequency of contacts except in bites. The males deliver bites nearly twice as often as do the females in the same time period.

3. When compared, the rankings within the categories of aggression and of submission are, respectively. correlated. There are no significant changes in rankings between the two sets of observations.

4. There are no significant changes between sets 1 and 2 in frequencies of contacts among males. Among females, the frequencies of neck arching, bite, and tail waving show a significant decrease, while the unclassified category shows a significant increase. This suggests the 
possibility of learning; however, verification or rejection of this would require further investigations with both sexes.

5. For both males and females, comparison of rankings in aggression and subnission shows significant correlations. This indicates that the categories reflect a dominance-subordinance relationship.

6. When the ranking for each category of aggression and subraission is correlated with the total ranking, it appears that no one category contributes a disproportionate share to the total. The touch, approach, and bite categories have the highest correlations with the total in each sex.

7. In fenales the rankings for all aggressive categories and for all submissive categorles have a significant negative correlation respectively, when compared with the rankings for the unclassified category. None of these correlations is significant in the males. This difference is considered to be clue to an inclusion by the observer of wny unrecognized aggressive contacts in those identified as unclassified.

8. When rankings between every possible pair of the aggressive categoriea are compared, all are found to be significant among the females, only two among the males. 
of such correlations in submissive categories, only one is not significant. The exceptions to the significant correlatlons are shown to be due to the erratic behavior of two or three animals.

9. It is shown that approach, touch, and bite have a closer relationship with each other than with neck arching or tail vibration.

10. The possibility blat neck arching and tail vibration might be considered as challenges is weightd. This isrrejected in favor of the conclusion that they represent the agitation and disturbance of the animals when they are involved in paix-mate contacts.

11. The heavier males tend to be the more aggressive, but this is not true of the females.

12. A ranking based on number of movements by isolated females, when compared with rankings for aggression, Indicates that the more active females tend to rank higher in aggression.

13. A subjective description of the male lizards is found to reflect individual differences recognizable after long periods of observation, and these are compatible with objective conclusions.

14. A record of the location of bites received 
reveals that a greater number than would be expected by chance is received upon the tail. This is considered to be a behavioral adaptation related to the morphological adaptation of autotony. 


\section{LITERATURE CITED}

Allee, W. C. 1951. Cooperation among Animals, with Human Implications, Schuman, New York. $233 \mathrm{pp}$.

Allee, W. C., and J. C. Dickinson. 1954. Dominance and subordination in the smooth dogfish, Mustelus canis (Mitchil1). Physiol. Zool.. 27(4): 356-364.

Allee, W. C., D. Foreman, E. M. Banks, and C. H. Holabird. 1955. Effects of an androgen on dominance and subordinance in $\mathrm{six}$ common breeds of Gallus gallus. Phystol. Zool., 28(2): 89-115.

Allee, W. C.. B. Greenberg, G. M. Rosenthal, and P. Frank. 1948. Some effects of social organization on growth in the green sunfish, Lepomis cyanellus. Jour. Exp. Zool.. 108: 1-19.

Andrew, R. J. 1957. Influence of hunger on aggressive behavior in certain buntings of the genus Emberiza. Physiol. 2001., $30(2): 177-185$.

Baerends, G. P. 1958. The contribution of ethology to the study of the causation of behaviour. Acta Physiol. Pharmacol. Neerlandica, 7:466-499.

Baerends, G. P., and J. M. Baerends-van Roon. 1950. An introduction to the study of the ethology of cichlid fishes. Behaviour, Supplement 1: 1-243.

Balph, D. F., and A. W. Stokes. 1959. Notes on the behavior of deer mice (Peromyscus maniculatus rufinus). Proc. Utah Acad. Sci., Arts and Letters, 37: 55-62.

Banks, E. M. 1956. Social organization in red jungle fowl hens (Gallus gallus subsp.). Ecology, 37: 239-248.

Banks, E. M., and C. W. Allee. 1957. Some relations between flock size and agonistic behavior in domestic hens. Phys1ol. Zool.. 30(3): 255-268. 
Bovjberg, R. V. 1956. Some factors affecting aggressive behavior in crayfish. Physiol. Zool.. 29: 127-136.

Boyd. H. 1953. On encounters between wild White-Fronted Geese in winter flocks. Behaviour, 5(2): 85-129.

Braddock, J. C. 1945. Some aspects of the dominancesubordination relationship in the fish platypoecilus maculatus. Phys1ol. Zool.. 18(2): 176-195.

- 1949. The effect of prior residence upon dominance in the flsh, Platypoecilus maculatus. Physiol. Zool.. 22: 161-169.

Braddock, J. C., and Z. I. Braddock. 1955. Aggressive behavior among females of the slamese fighting fish. Betta splendens. Physiol. Zool., 28(2): 152-172.

Brain. Anne D. 1949. Dominance in the great tit Parus malor. Scottish Nat., 61(3): 144-155.

Carpenter, C. C. 1960. Aggressive behaviour and social dominance in the $81 x-1$ ined race-runner (Cnemidophorus sexlineatus). Animal Behaviour, $8(1 / 2): 61-66$.

Carpenter, C. C., and G. Grubits III. 1960. Dominance shifts in the tree 11zard (Urosaurus ornatus--Iguan1dae). Southwestern Nat., 5(3): 123-128.

Castoro, P., and A. M. Guhl. 1958. Palring behavior of pigeons related to aggressiveness and territory. Wilson Bul1.. 70(1): 57-69.

Chitty. D. 1952. Mortality among voles (Microtus agrestis) at Lake Vyrnivy, Montgomeryshire in 1936-9. Philos. Trans.. B236, pp. 505-552.

Clarke, J. R. 1956. The aggressive behav1or of the vole. Behavior, $9(1): 1-23$.

Collias. N. E. 1943. Statistical analysis of factors which make for success in initial encounters between hens. Am. Nat.. 77: 519-538.

1944. Aggressive behavior among vertebrate animals. Phys101. Zool. . 17: 83-123. 
Conant, R. 1958. A Fleld Guide to Reptiles and Amphiblans. Houghton Mifflin Co., Boston. $366 \mathrm{pp}$.

Crawford, M. P. 1942. Dominance and social behavior, for chimpanzees, in a non-compet1tive situation. J. Comp. Psychol.. 33: 267-277.

Darling, F. F. 1938. Bird Flocks and the Breeding Cycle. The University Press, Cambridge. 124 pp.

Davies, J. L. 1953. Colony size and reproduction in the grey seal. Proc. Zool. Soc. London, 123(11): $327-332$.

Denenberg, V. H., and R. W. Bell. 1959. Relationship between soclal reactions and avoidance conditioning. Phys. Zool., 32: 51-56.

Douglis, M. 1948. Social factors influencing the hierarchies of small flocks of domestic hen: The interaction between resident and part-time members of organlzed flocks. Physiol. Zool., 21: 147-182.

Evans, L. T. 1951. Fleld study of the social behavior of the black 11zard, Ctenosaura pectinata. Amer. Mus. Novitates, \#1493, Mar. 5, 1951: 1-26.

- 1946. Social behavior of the 11zard, Sceloporus grammicus microlepldotus. Anat. Rec., vol. 94, pp. 53-54 (abstract).

- 1936. A study of a social hierarchy in the lizard, Anolis carolinensis. Jour. Genet. Psychol., 48: 88-111.

Fitch, H. S. 1940. A Eleld study of the growth and behavior of the fence 11zard. Univ. Cal. Publ. Zool., 44(2): $151-172$.

- 1954. Life history and ecology of the Elve-lined skink, Eumeces fasciatus. Univ. Kan. Publ.. Mus. Nat. Hist., $8(1): 1-56$.

Fredericson, E., and E. Ann Birnbaum. 1954. competitive fighting between mice with different hereditary backgrounds. Jour. Genet. Psychol., 85(2): 271-281. 
Ginsburg, B., and w. C. Allee. 1942. Some effects of conditioning on social dominance and subordination in inbred strains of mice. Physlol. Z0ol., 15: 485-506.

Goethe, Friedrich. 1953. Soclale Hierarchie in Aufzuchtsschwarm der silbermowen. Zeltschr. Tlerpsychol.. $10(1): 44-50$.

Gordon, R. E. 1957. The blology and blodemography of Anolis carolinensis carolinensis volgt. Dissert. Abst.. 17(3): 698 .

Grant, W. C., Jr. 1955. Territorialism in two specles of salamanders. Science, 121(3135): 137.

Greenberg, B. 1947. Some relations between territory, social hierarchy and leadership in the green sunf1sh, Lepomis cyanellus. Physiol. Zool., 20: 267-299.

Greenberg, B., and G. K. Noble. 1944. Soclal behavior of the American chameleon, Anolis carolinensis Volgt. Physiol. Zool.., 17: 392-439.

Guhl, A. M. 1945. Some observations and experiments on soclal behavior in the domestic fowl. Trans. Kansas_Acad._Sci.., 47(3): 337-341.

Guhl, A. M., and W. C. Allee. 1944. Some measureable effects of soclal organization in flocks of hens. Phys101. Z001.., 17(3): 320-347.

Haubrich, R. R. 1961. Herarchlcal behavior In the South African clawed frog, Xenopus laevis Daudin. Animal Behaviour, 9(1-2): 71-76.

Hunsaker, D. 1962. Ethological 1solating mechanisms in the sceloporus torquatus group of 11zards. Evolution, 16: 62-74.

Jenkens, D. W. 1944. Territory as a result of despotism and social organlzation in geese. Auk, 61 (1): 30-47.

Kilham, Lawrence. 1961. Aggressiveness of migrant myrtle warblers toward woodpeckers and other birds. Auk. $78(2)=261$. 
Kunmer, Hans. 1957. Sociales verhalten einer mantelpaviangruppe. Beiheft zur Schweizerischen Zeitschrift fur Psychol... 33: 1-91.

Laskey, Amella R. 1950. Cowblrd behavior. Wilson Bull... $62(4): 157-174$.

Lorenz, K. 1935. Der Kumpan in der unwelt des Vogels. Jour. f. Ornithol.. 83: 137-213, 289-413.

- 1941. Vergleichende bewegungsstudien an anatinen. Jour. f. Ornithol., 89 (Festschrift Heinroth): 194-294.

- 1952. King Solomon's Ring. Thomas Y. Crowell Co.. New York. 202 pp.

Lowe, C. H., Jr, 1948. Territorial behavior in snakes and the so-called courtship dance. Herpetologica, 4(4): 129-135.

Lowe, C. H., Jr., and K. S. Norris. 1950. Aggressive behavior in male sidewinders Crotalus cerastes, with a discussion of aggressive behavior and territoriality in snakes. Chicago Acad. Sc1. Nat. Hist. Misc., 66: 1-13.

Lowe, C. H. , and W. H. Woodin III. 1954. Aggressive Behavior in Phrymosoma. Herpetologica, $10(1): 48$.

Lutz. Bertha. 1960. Fighting and an incipient notion of territory in male tree frogs. Copela, 1960(1): 61-63.

Martof, B. S. 1953. Territoriallty in the green frog, Rana= clamitans. Ecology, 34: 165-174.

Maslow, A. H. 1940. Dominance quallty and soclal behavior In infra-human primates. J. Soc. Psychol.., 11: 313-324.

Masure, R. K.., and W. C. Allee. 1934. The soctal order in flocks of the common chicken and the pigeon. Auk, 51: 306-327. 
Mchugh, T. 1958. Soclal behavior of the American buffalo (Bison bison bison). Zoologica (N.Y.), 43(1): $1-40$.

Miller, Malcolm R. 1951. Some aspects of the life history of the Yucca night 11zard, Xantusia vigilis. Copela, $1951(2): 114-120$.

Miller, R. E., J. V. Murphy and I. A. Mirsky. 1955. Modsf1cation of social dominance in a group of monkeys by interanimal conditioning. Jour. Comp. and Physiol. Psychol., 48(5): 392-396.

Newman, M. A. 1956. Social behavior and interspecific competition in two trout species. Physiol. Zool.. 29: 64-81.

Noble, G. K., and H. T. Bradley. 1933. The mating behavior of 11zards; Its bearing on the theory of sexual se1ection. Ann. New York Acad. Sc1.. 35(Art. 2): 25-100.

Pard1, L. 1946. Sui fenomani di "dominazlone" nelle societa animal1. Hist. Nat. (Rome), $1(1): 9-16$.

Parrish, F. K. 1958. Miscellaneous observations on the behavior of captive sea turtles. Bul1. Marine Sci. Gulf and Caribbean, $8(4): 348-355$.

Pearson, P. G. 1955. Population ecology of the spadefoot toad, Scaphiopus h. holbrookl (Harlan). Ecological Monographs, 25: 233-267.

Petit, G. 1928. Sur le Chalarodon madagascarlensis Peters. Bull. Soc. Zool. de France, 53: 401-405.

Potter, J. H. 1949. Dominance relations between aifferent breeds of domestic hens. Physlol. Zool. , 22(3): 261-280.

Raney, E. C., and R. A. Josephson. 1954. Record of combat in the snapping turtle, Chelydra serpentina. Copela. 1954(3): 228. 
Reed, C. A. 1960. Polyphyletic or monophyletic ancestry of mamnals, or: what is a class? Evolution, 14(3): 314-322.

Ruibal, Rodolfo. 1960. Inter- and Intraspecific behavior of 1izards. Anat. Rec.., 137(3): 390 (abstract).

Sabine, W. S. 1949. Dominance in winter flocks of juncos and tree sparrows. Phystol. Z00l. . 22: 64-85.

Schein, M. W., and M. H. Fohrman. 1955. Social domlnance relationships in a herd of dairy cattle. Brit. $J$. of Animal Behavior, $3(2): 45-55$.

Schjelderup-Ebbe, F. 1913. Honsenes stemme fldxag t1l Honsenes psykologi naturen, 37: 262-276.

1922. Beltrage zur Soctalpsychologle des Haushuhns. Zeitschr.f. Psychol.. 88: 225-252.

1935. Social behavior of birds; cited in G. A. MurchInson, A Handbook of Social Psychology. Worchester, pp. 947-972.

Scott, J. P. 1948. Dominance and the frustration-aggression hypothesis. Phys. Zool.., 21: 31-39.

Scott, J. P., and E. Fredericson. 1951. The causes of fighting in mice and rats. Physiol. Zool., 24: 273-309.

Siegel, S. 1956. Nonparametric Statistics for the Behavioral Sclences. McGraw-Hill Book Co., Inc., New York. $312 \mathrm{pp}$.

Simpson, G. G. 1960. Diagnosis of the classes Reptilia and Mammalia. Evolution, 14(3): 388-392.

Stebbins, R. C. 1944. Field notes on a 11zard, the mountain swift, with special reference to territorial behavior. Ecology, 25: 233-245.

Stringer, G. E., and W. S. Hoar. 1955. Aggressive behavior of the underyearling Kamloops trout. Canadian J. Z001.. 33(3): 148-160. 
Taylor, E. H. 1932. Eumeces Inexpectatus: a new American lizard of the family Scincldae. Undv. Kans. Scl. Bu11., XX, 1932: 251-258.

Test, F. H. 1954. Social aggressiveness in an amphiblan. Science, $120(3108)$ : 140 .

Thompson, W. L. 1960. Agonistic behavior in the house finch. II: Factors in aggressiveness and sociality. Condor, $62(5): 378-402$.

Tinbergen, N. 1942. An objectivistic study of the Innate behaviour of animals. Series D. Bibliothica Biotheoretica. V. 1. part 2. E. J. Brill, London. pp. 39-98.

- 1948. Social releasers and the experimental method regulred for their atudy. W1lson Bull.. 60 : $6-52$.

1953. Social Behaviour In Animals, with Special References to Vertebrates. Methuen and co., Itd., London. John Wiley and Sons, Inc., New York. 150 pp.

Uhrich, Jacob. 1938. The social hierarchy in albino mice. Jour. Comp. Psychol., 25: 373-413.

Van Valen, Leigh. 1960. Therapsids as mamals. Evolution, $14(3): 304-313$.

Wharton, C. H. 1958. The ecology of the cottonmouths Agkistrodon piscirorus piscivorus Lacepede of sea Horse Key, Florida. Doctoral Dissertation, University of Florida, Galnesville.

Winn, H. E. 1958. Comparative reproductive behavior and ecology of fourteen species of darters (P1scesPercidae). Ecolog1cal Monographs, 28: 155-191. 


\section{BIOGRAPHY}

Cleo Duke W1lder, Jr., was born in Macon, Georgia, on September 24, 1925. He spent his public school years in Paris, Tennessee, graduating from high school in 1943.

After two semesters at Tulane University, he was drafted Into the United States Naval Reserve In Apr11. 1944. In June, 1944, he was assigned to the V-12 offlcers' training program at the University of North Carolina. He recelved his discharge and comnission as Ensign, USNR, in June, 1946. He recelved his Bachelor of Arts in English from the University of North Carolina in June, 1948, and h1s Master of Science in zoology from the University of Tennessee in August, 1951.

After serving as Instructur in Blology at Presbyterlan College from september, 1951, unt11 August, 1953; he entered the Graduate School of the university of Florida where he held an assistantship in the Florida state Museum and several graduate and teaching assistantships in the Department of Blology and C-6 program. He held a fellowship in the School of Arts and Sciences in the summer of 1956. 
In the year 1957-58, he was employed as Sixth Grade Teacher, Alachua Elementary School, Alachua, Florida. He was Assistant Professor of Blology, Memphis state University, from September, 1959, unt11 June, 1962. He accepted an appointment as Assistant Professor of zoology at Virginia Polytechnic Institute effective september, 1962.

In 1950 he married the former Betty Rhea and they have two sons.

Cleo Duke wilder, Jr., 1s a member of sigma $\mathrm{XI}$, Phi Sigma, American Society of Ichthyologists and Herpetologists, Herpetologists' League, American Society of Mammalogists, Society for the Study of Evolution, The wilderness society, Tennessee Academy of Science, Association of Southeastern Biologists, and American Association of University Professors. 
This thesis was prepared under the direction of the chairman of the candidate's supervisory committee and has been approved by all members of that committee. It was submilted to the Dean of the College of Arts and Sciences and to the Graduate Council, and was approved as partial fulfillment of the requirements for the degree of Doctor of Philosophy.

June, 1962

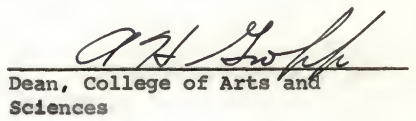
sciences

Dean, Graduate school

SUPERVISORY COMMITTEE:
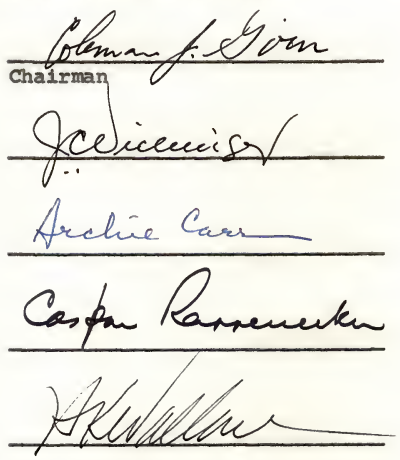